\title{
農薬科学研究におけるQSARの活用
}

\author{
中川好秋* \\ 京都大学大学院農学研究科
}

（2014年1月6日受理）

\section{Practice of QSAR in pesticide research}

\author{
Yoshiaki NAKAGAWA \\ Graduate School of Agriculture, Kyoto University, \\ Kitashirakawa Oiwake-cho, Sakyo-ku, Kyoto 606-8502, Japan
}

Keywords: classical QSAR, Hansch-Fujita method, chitin synthesis inhibitors, benzoylphenylureas.

\section{はじめに}

本稿では, QSAR (Quantitative Structure-activity Relationship）解析の原点である classical QSAR（Hansch-Fujita） 解析 ${ }^{1)}$ を, 実際にどのように進めていくかについて, ベンゾ イルフェニルウレア（Benzoylphenylurea: BPU）系殺虫剂を 例にとり解説する。原報はすでに学術雑誌に掲載されている ので，そちらをも適宜参考にして頂きたい. なお本研究は, Hansch-Fujita解析法の生みの親であるとともに, 筆者の大 学院当時の指導教官であった藤田稔夫先生のもとで一から始 めたもので, 初心者にとっては適当な題材であると思う.

\section{1. ベンゾイルフェニルウレア類}

BPUは, 1972年にオランダの Philip Duphar社のVan Daalen らによって除草剂の探索中にたまたま見いだされた 殺虫性化合物である ${ }^{2)}$. BPU系化合物は，それまでの殺虫剤 の作用点（神経系や呼吸系）とは異なり，代謝系を攻撃する ことによって成育を制御する。すなわち，表皮の主成分であ

\footnotetext{
* $=$ 606-8502 京都市左京区北白川追分町

E-mail: naka@kais.kyoto-u.ac.jp

(c) 日本農薬学会
}

るキチンの生合成を阻害し, 幼虫を脱皮不全に導いて致死効 果を発現する。しかし, 昆虫から調製した無細胞系のキチン 合成酵素を阻害せず，未だ真の作用機構は明らかになって いない、筆者は, カリフォルニア大学デービスの（故）松村 文夫先生のもとでBPUのひとつである diflubenzuron（図 1） の作用点について検討し, ある種のタンパク質のリン酸化と イオンチャネルの関与した輸送系がかかわっていることを提 唱した ${ }^{3)}$ が，未だ確認されていない゙).

最初に活性が見いだされたBPUはDu19111（図1）であ る. 実用的には, 土培蓄積と環境污染の少ないdiflubenzuron（図 1）が農業用殺虫剂として取り上げられた ${ }^{5)}$. のち に, 石原産業によって diflubenzuronより活性特性の優れた chlorfluazuron（図 1） が発明・開発された ${ }^{6)}$. その後も様々 な構造展開が行われ, 図 1 に示すように, 優れた類縁体が開 発され, 農業用殺虫剂, 殺ダ二剂, また殺シロアリ剂として も実用化にいたっている7). また，BPU類以外にも，キチン 合成を阻害する剤が報告されている ${ }^{8,9)}$.

BPU類は図 1, 2 に示すように，ウレア構造 $\left[\mathrm{NH}_{2} \mathrm{C}(=\mathrm{O})\right.$ $\mathrm{NH}_{2}$ ] の両端の窒素原子が benzoyl基（A環）と phenyl基 (B環) で置換された構造を持ち，2個のベンゼン環に様々な 置換基を導入して構造修飾することが可能である. 図 1 に示 したような種々の化合物の活性に対して，置換基がどのよう 
<smiles>O=C(NC(=O)c1c(Cl)cccc1Cl)Nc1ccc(Cl)c(Cl)c1</smiles>

Du19111

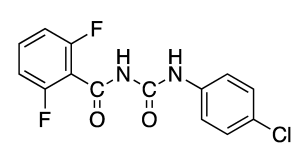

Diflubenzuron<smiles>O=C(NC(=O)c1c(F)cccc1F)Nc1cc(Cl)c(Oc2ncc(C(F)(F)F)cc2Cl)c(Cl)c1</smiles>

Chlorfluazuron

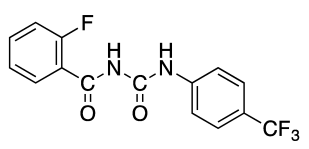

Perfluron

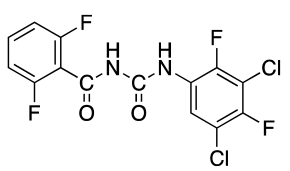

Teflubenzuron

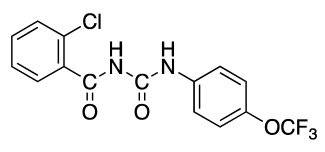

Triflumuron

Novaluron

ルウレア類の構造

な役割を果たしているかを解明しょうとするQSAR解析の ために，筆者らは $\mathrm{A}$ 環置換基を 2,6- $\mathrm{F}_{2}$ に固定し，B環に様々 な置換基を導入した化合物群（Series I化合物 $)^{10)}$, B 環の置 換基を 4- $\mathrm{Cl}$ に固定し $\mathrm{A}$ 環に様々な置換基を導入した化合物 群 (Series II 化合物 $)^{11)}$ を合成した（図2)。この場合，合成 設計において，あらかじめ種々の物理化学的パラメーター間 の共直線性ができるだけ小さくなるように置換基を選ぶこと が極めて重要である．殺虫活性の評価には，無菌的に人工飼 育した稲の害虫ニカメイガ（Chilo suppressalis）の第3令幼 虫（二カメイチュウ）を用い, 半数致死薬量 $\mathrm{LD}_{50}(\mathrm{mmol} /$ insect）の対数の逆数值 $\mathrm{pLD}_{50}$ を活性の指標とした ${ }^{10,11)}$. カ イコ (Bombyx mori) とハスモンヨトウ幼虫（Spodoptera litura）に対しても殺虫活性 $\mathrm{pLD}_{50}{ }^{12)}$ を，また必要に応じ， ニカメイチュウの培養表皮系におけるキチン合成阻害活性 $\mathrm{pIC}_{50}\left(\mathrm{IC}_{50}: 50 \%\right.$ 阻害濃度 M）を解析に用いた ${ }^{13,14)}$.

ここで, 再現性のある活性指標を得ることができる検定 系であることが必須条件である.すなわち，ひとつの化合物 の活性指標（ここでは $\mathrm{pLD}_{50}$ ）が，測定ごとにさ1.0（1/10, 10 倍）も変化するようでは定量的解析に意味がない，通常 は殺虫活性指標の平均值の標準偏差がさ0.3（1/2,2 倍）以内 であることが望ましい. われわれの活性測定系では, 測定 された殺虫活性 $\mathrm{pLD}_{50}$ およびキチン合成阻害活性 $\mathrm{pIC}_{50}$ の值 は，ほとんどェ 0.3 の範囲におさまる再現性の良好なことが 確かめられている. また, 殺虫試験においては, しばしば共 力剂 (代謝阻害剂) が用いられる。置換体によっては, 代謝 分解が他の誘導体に比べると速く, それ自身が持っている本 来の活性が現れないからである。ただし, 代謝阻害剤の薬量 をあまり上げすぎると，それ自体が昆虫本来の成長に影響を 与えることがあるので，特に成育制御剤などの活性評価では その処理に注意が必要である。本稿では，代謝阻害剤を用い ない場合の活性は $\mathrm{pLD}_{50}$ (None) と表記されている。 また, 酸化代謝阻害剂 piperonyl butoxide（PB）を用いて活性評価 $\left[\mathrm{pLD}_{50}(\mathrm{~PB})\right]$ を行い, 場合に応じて加水分解的解毒代謝も 考慮し, 加水分解代謝阻害剂 DEF（S,S,S-tributhylphosphorotrithioate）を共力剤として活性 $\left[\mathrm{pLD}_{50}(\mathrm{DEF})\right]$ を測定し た. その結果, 置換基の構造によっては活性が顕著に上昇し
た ${ }^{15)}$. 理想的には，酸化代謝と加水分解代謝が同時に抑制さ れる条件 $\left[\mathrm{pLD}_{50}(\mathrm{~PB}+\mathrm{DEF})\right]$ が好ましいが，その条件で は本来の成育が顕著に抑制されることが判明した。したがっ て, PB とDEFの併用は避け，それぞれ単剤を使用して活性 を測定し, それぞれの值の変動を観察し, 解析の結果に対し て，代謝による影響ができるだけ少なくなるよう考慮した。

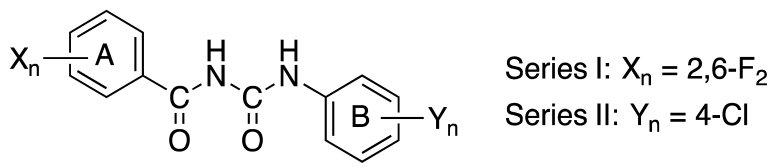

図2. QSARに用いる置換ベンゾイルフェニルウレア類

\section{2. ニカメイチュウに対する殺虫活性のQSAR}

\subsection{Series-I化合物におけるフェニル環（B環）上の置 換基効果}

まず，ハロゲンや単純なアルキルやアルコキシ基，二トロ 基, シアノ基で置換された化合物を用いて二カメイチュウに 対する殺虫活性を測定した。フェニル環（B環）上のpara位 置換基を変えた BPU類（Series I : 図2）の活性と置換基定 数を表 1 に挙げた.この表には $\mathrm{pLD}_{50}$ が求められなかった化 合物に関し, 括弧内に, 最大薬量での致死率が記載されて いる．この情報は重要であり, 例えば化合物 2 において, 最 大薬量での致死率として $50 \%$ に近い值（45\%）が得られてい る.このことは, $\mathrm{LD}_{50}$ が最大薬量に近いことを示し, 得ら れたQSAR式の予測性を確認するために用いることができ るのである. 化合物 $\mathbf{1} と \mathbf{2}$ の殺虫活性を比較する場合に, 致 死率（\%）の值が求められていないと, 無置換体（1）と F 体（2）のどちらが高い活性を示すかわからない。この殺虫 試験法では，1濃度あたり20匹の幼虫を用いている．場合 によっては薬剤の濃度の低いとき濃度に関係なく 1 匹程度は 死ぬことがある。それ以上の濃度で, 濃度依存的に死ぬ場 合は，薬剤による活性発現によるものと考えて良い. $\mathrm{CH}_{3}$ 体（6）は, $\mathrm{OCH}_{3}$ 体（15） や $\mathrm{OC}_{2} \mathrm{H}_{5}$ 体（16）とともに溶解 度が不十分のため, 処理溶液の濃度を上げることができず $\mathrm{pLD}_{50}$ が求められなかったのである. 
表 1.フェニル環para位に種々の置換基をもつBPU類の殺虫活性と置換基定数

\begin{tabular}{|c|c|c|c|c|c|c|c|c|c|c|}
\hline & \multirow{2}{*}{ 化合物 } & \multicolumn{6}{|c|}{$\mathrm{pLD}_{50}(\mathrm{mmol} /$ insect $)$} & \multirow{2}{*}{\multicolumn{3}{|c|}{ 置換基パラメーター }} \\
\hline & & \multirow{2}{*}{ None ${ }^{a)}$} & \multicolumn{5}{|c|}{$\mathrm{PB}$} & & & \\
\hline No. & $\mathrm{Y}$ & & 実測值 & $\begin{array}{l}\text { 計算值 } \\
\text { 式 (4) }\end{array}$ & 差 $^{b)}$ & $\begin{array}{l}\text { 計算值 } \\
\text { 式（10） }\end{array}$ & 差 $^{c}$ & $\pi$ & $\sigma_{\mathrm{I}}$ & $\Delta \mathrm{B} 5$ \\
\hline 1 & $\mathrm{H}$ & $<4.60(0 \%)$ & 4.93 & 4.97 & -0.04 & 5.15 & -0.22 & 0.00 & 0.00 & 0.00 \\
\hline 2 & $\mathrm{~F}$ & $<4.60(45 \%)$ & 5.69 & 5.66 & 0.03 & 5.74 & -0.05 & 0.19 & 0.54 & 0.35 \\
\hline 3 & $\mathrm{Cl}$ & 6.50 & 6.64 & 6.29 & 0.35 & 6.23 & 0.41 & 0.88 & 0.47 & 0.80 \\
\hline 4 & $\mathrm{Br}$ & 6.51 & 6.72 & 6.40 & 0.32 & 6.34 & 0.38 & 1.02 & 0.47 & 0.95 \\
\hline 5 & I & 6.27 & 6.75 & 6.50 & 0.25 & 6.41 & 0.34 & 1.22 & 0.40 & 1.15 \\
\hline 6 & $\mathrm{CH}_{3}$ & & $<4.60(22 \%)$ & 5.26 & & & & 0.37 & -0.01 & 1.04 \\
\hline 7 & $\mathrm{C}_{2} \mathrm{H}_{5}$ & & 4.83 & 5.58 & -0.75 & 5.90 & -1.07 & 0.82 & -0.01 & 2.17 \\
\hline 8 & $n-\operatorname{Pr}$ & & 5.86 & 6.03 & -0.17 & 6.14 & -0.28 & 1.34 & -0.01 & 2.49 \\
\hline 9 & $i-\operatorname{Pr}$ & & 6.00 & 6.06 & -0.06 & 6.15 & -0.15 & 1.30 & 0.01 & 2.17 \\
\hline 10 & $n-\mathrm{Bu}$ & $<4.60(45 \%)$ & 6.46 & 6.30 & 0.14 & 6.50 & -0.04 & 1.86 & -0.01 & 3.54 \\
\hline 11 & $t-\mathrm{Bu}$ & 5.24 & 6.31 & 6.36 & -0.05 & 6.41 & -0.10 & 1.68 & -0.01 & 2.17 \\
\hline 12 & $n$-Hex & 5.56 & 6.75 & 6.69 & 0.06 & 6.71 & 0.04 & 2.85 & -0.03 & 4.96 \\
\hline 13 & $n$-Hep & 5.27 & 6.77 & 6.83 & -0.06 & 6.80 & -0.03 & 3.35 & -0.04 & 5.39 \\
\hline 14 & $\mathrm{~N}=\mathrm{NPh}$ & 6.50 & 6.49 & 6.67 & -0.18 & 6.57 & -0.08 & 1.94 & 0.28 & 3.31 \\
\hline 15 & $\mathrm{OCH}_{3}$ & & $<4.30(10 \%)$ & 4.63 & & & & -0.26 & 0.30 & 2.07 \\
\hline 16 & $\mathrm{OC}_{2} \mathrm{H}_{5}$ & & $<4.60(22 \%)$ & 5.07 & & & & 0.14 & 0.28 & 2.36 \\
\hline 17 & $\mathrm{OPh}$ & & 5.97 & 6.55 & -0.58 & 6.59 & -0.62 & 1.93 & 0.40 & 4.89 \\
\hline 18 & $\mathrm{CF}_{3}$ & 6.70 & 6.92 & 6.52 & 0.40 & 6.35 & 0.57 & 1.32 & 0.40 & 1.61 \\
\hline 19 & $\mathrm{NO}_{2}$ & $<5.08(0 \%)$ & $<5.08(0 \%)$ & 5.93 & & & & 0.45 & 0.67 & 1.44 \\
\hline 20 & $\mathrm{CN}$ & 4.90 & 5.35 & 5.50 & -0.15 & 5.45 & -0.10 & 0.06 & 0.57 & 0.60 \\
\hline 21 & $\mathrm{OCH}_{2} \mathrm{Ph}$ & & 6.75 & 6.45 & 0.30 & 6.43 & 0.32 & 1.35 & 0.43 & 2.50 \\
\hline 22 & $\mathrm{OCH}_{2} \mathrm{Ph}(2-\mathrm{F})$ & & 6.74 & 6.50 & 0.24 & 6.48 & 0.26 & 1.49 & 0.43 & 3.02 \\
\hline 23 & $\mathrm{OCH}_{2} \mathrm{Ph}(3-\mathrm{F})$ & & 6.59 & 6.50 & 0.09 & 6.49 & 0.10 & 1.49 & 0.43 & 3.01 \\
\hline 24 & $\mathrm{OCH}_{2} \mathrm{Ph}(4-\mathrm{Cl})$ & & 6.53 & 7.01 & -0.48 & 6.85 & -0.32 & 2.06 & 0.43 & 2.50 \\
\hline 25 & $\mathrm{OCH}_{2} \mathrm{Ph}\left(2,4-\mathrm{Cl}_{2}\right)$ & & 6.87 & 7.25 & -0.38 & 7.05 & -0.18 & 2.77 & 0.43 & 3.80 \\
\hline 26 & $\mathrm{OCH}_{2} \mathrm{Ph}\left(3-\mathrm{CF}_{3}\right)$ & & 6.72 & 6.89 & -0.17 & 6.81 & -0.09 & 2.23 & 0.43 & 4.10 \\
\hline 27 & $\mathrm{OCH}_{2} \mathrm{Ph}\left(3,4-\mathrm{Me}_{2}\right)$ & & 7.01 & 7.11 & -0.10 & 6.95 & 0.06 & 2.47 & 0.43 & 3.58 \\
\hline 28 & $\mathrm{OCH}_{2} \mathrm{Ph}\left(3-\mathrm{NO}_{2}\right)$ & & 5.63 & 5.97 & -0.34 & 6.12 & -0.49 & 1.07 & 0.43 & 4.13 \\
\hline 29 & $\mathrm{OCH}_{2} \mathrm{Ph}(2-\mathrm{CN})$ & & $<5.05$ & 5.18 & & & & 0.78 & 0.43 & 4.32 \\
\hline
\end{tabular}

a) 空欄：活性未測定. ${ }^{b)}$ 実測值から式（4）による計算值を差し引いた值. ${ }^{c)}$ 実測值から式（10）による計算值を差し引いた值.

回帰分析を行う前に，殺虫活性データを吟味し，データの 変化の様子が置換基の物理化学パラメーターのうちのいず れかの変化の様子に類似しているか（直線的に関係している のか）を定性的に検討する. 活性データの変化がいずれかの パラメーターの変化に対応する傾向があれば，そのパラメー ターを用いて回帰分析（1次）を行ってみる。また，一つの パラメーターだけでは不十分の場合, 1次の回帰式から得ら れた計算值と実測值との差について, 別のパラメーターの変
化との対応を検討する，あるいは，経験を積めば，同時に2 つ（あるいは3つ）のパラメーターを使って解析することも 可能になる. 計算はコンピューターに頼って行う. 有意な QSAR式が得られたら, 計算值と実測值とを比較し, もしも その差と類似の変化をするパラメーターがあれば，そのパラ メーターを加え回帰分析を繰り返すのである.

もう一度, 表 1 を見て頂きたい. 酸化代謝分解の抑制され た条件下での無置換体（1）の $\mathrm{pLD}_{50}$ （PB）は，B環パラ位 
にハロゲンを導入すると $\mathrm{F}(2), \mathrm{Cl}$ (3), $\mathrm{Br}$ (4)， I（5）の 順序に活性が上昇する。 $\mathrm{CH}_{3}$ 基（6）の導入によって活性 は低下するが， $\mathrm{C}_{2} \mathrm{H}_{5}$ 体（7）では無置換体（1）と同程度の 活性に戻る.アルキル鎖を $n-\operatorname{Pr}(\mathbf{8}), n-\mathrm{Bu}(\mathbf{1 0}), n-\mathrm{Hex}$ （12）と伸ばしていくと活性は顕著に増大するが, $n$-Hep 体（13）において頭打ちとなる. また, 電子求引性の置換 基 $\mathrm{CF}_{3}$ (18), $\mathrm{NO}_{2}$ (19), $\mathrm{CN}(20)$ ，の導入により， $\mathrm{CF}_{3}$ 体 （18）では活性は顕著に増大する一方, $\mathrm{NO}_{2}$ 体（19）では活 性值を求めることができないほど活性は低い. 以上の結果か ら，まず置換基の疎水性が重要なパラメーターであることが

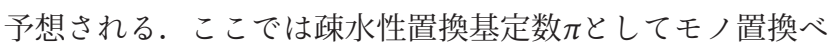
ンゼンからではなく, 置換アセトアニリドの $\log \mathrm{P}$ から求め

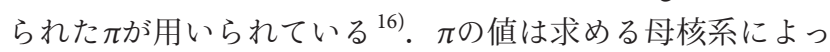
て異なるので，BPUのB 環部の環境に類似したアニリド系

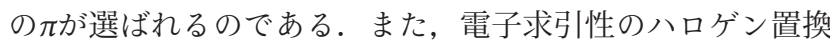
体の方が電子供与性のアルキル基より活性を高めることか ら, 電子的効果も重要であり, 結果として置換基の疎水性と 電子効果が共に活性強度に関与していることがわかる。電子 求引性パラメーターとして種々のハメット型定数を検討し た結果, ここでは誘起的電子求引性パラメーター $\sigma_{\mathrm{I}}$ が最も良 好な相関関係を与える電子的パラメーターとして選ばれ， $\sigma_{\mathrm{I}}$ どを用いて回帰分析が行われた。

まず，共力剂を含まない条件で $\mathrm{pLD}_{50}$ 值を求めることが できた2,6- $\mathrm{F}_{2}$ 置換体は9化合物（表 1: 3-5, 11-14，18，20） であり, パラメーターの数に比べ化合物数が少ない（一つ のパラメーターに対して5化合物が一応の基準)。そこで, 対応する 2,6- $\mathrm{Cl}_{2}$ 置換体の 7 化合物（図 $2: \mathrm{X}=2,6-\mathrm{Cl}_{2} ; \mathrm{Y}=\mathrm{Cl}$, $\mathrm{Br}, \mathrm{I}, \mathrm{CF}_{3}, \mathrm{NO}_{2}, t-\mathrm{Bu}, \mathrm{N}=\mathrm{NPh}$ ) を加えて解析が行われ た．本稿ではこれら化合物の活性は示していない，種々検討 の結果，16個の化合物に対して式（1）を導かれた ${ }^{17)}$.

$$
\begin{aligned}
\mathrm{pLD}_{50}(\text { None })= & 2.94( \pm 1.22) \sigma_{\mathrm{I}}+2.53( \pm 0.72) \pi \\
& -0.42( \pm 0.20) \pi^{2}-0.30( \pm 0.34) \Delta \mathrm{B} 5 \\
& -0.66( \pm 0.29) \mathrm{I}+3.22( \pm 0.97) \\
& n=16, \quad s=0.238, \quad r=0.942
\end{aligned}
$$

式（1）に扔いて，括弧内の数字はそれぞれの係数の 95\%信頼限界を示している，nは解析に用いた化合物数，s は標準偏差，rは相関係数を表している．相関式の $F$ 検定 を行って，相関式の有意性を論じることもある。すなわ ち，式（1）において， $\Delta B 5$ の項の有意性は $95 \%$ 以上では ない $(92 \%)$ が, 式（1）自体はF検定 $\left(F_{5,10}=15.817\right)$ で 99.9\%以上で有意である．式（1）の誘導には，5種のパラ メーターが用いられていて, 化合物数が基準より少ないが, 式（2）の結果と照らし合わせて，妥当な結果と考えられ た。すでに述べたように $\sigma_{\mathrm{I}}$ は誘起的電子求引性を表すパラ

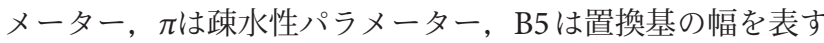
Verloop の立体パラメーターで， $\Delta \mathrm{B} 5$ はそれぞれの置換基の
B5 值から水素原子の B5 值（1.00）を差し引いた值である。I はベンゾイル部の置換基が $2,6-\mathrm{F}_{2}$ の場合に $0,2,6-\mathrm{Cl}_{2}$ の場合 に 1 をとる擬変数である.I項の係数が- 0.66 であることは, 2,6- $\mathrm{Cl}_{2}$ 体の活性は, B環パラ置換基が対応する2,6- $\mathrm{F}_{2}$ 体に比 べ約 $1 / 5$ であることを示す $(\log 5=0.699)$. なお，式（1）に おいて, 電子的効果のうち共鳴効果成分の欠けていることに ついては後述する. 置換基定数（パラメーター）の詳細につ いては，実験技術講座の第 1 回 ${ }^{18)}$ ，第 3 回 ${ }^{19)}$ に詳しく書かれ ているので，参考にしていただきたい．

前に述べたように，生体内で代謝を受けやすい化合物は， 通常の条件下で殺虫試験を行っても, 本来の $\mathrm{LD}_{50}$ 值は正確 には求められない，そこで，酸化的な解毒代謝の阻害剂であ るPBを含む人工飼料を用いて飼育した幼虫を用いて活性を 測定した。 その結果，かなりの化合物の殺虫活性が大きく上 昇し, B 環置換基を種々に変化させた $2,6-\mathrm{F}_{2}$ 置換体だけでも 十分な数の誘導体（24化合物）に対して $\mathrm{pLD}_{50}(\mathrm{~PB})$ が得 られ，式（2）が導かれた。

$$
\begin{aligned}
\mathrm{pLD}_{50}(\mathrm{~PB})= & 1.06( \pm 0.60) \sigma_{\mathrm{I}}+1.57( \pm 0.54) \pi \\
& -0.17( \pm 0.14) \pi^{2}-0.31( \pm 0.16) \Delta \mathrm{B} 5 \\
& +4.93( \pm 0.41) \\
n= & 24, \quad s=0.290, \quad r=0.907 ; \quad \pi_{\text {opt }}=4.62
\end{aligned}
$$

式（2）において, 解析に用いているパラメーターの数 (4 個）は多すぎることはない，また， $\pi_{\mathrm{opt}}=4.62$ は $\mathrm{B}$ 環置換基 に関する最適の疎水性の值を示し, $1.57 \pi-0.17 \pi^{2}$ から求め られる最大值である。ここで，式（1）と（2）を比較してみ ると， $\sigma_{\mathrm{I}}$ の係数が大きく変化 $(2.94 \rightarrow 1.06)$ していること がわかる。つけ加えられた化合物の中には, 疎水性のかなり 大きな置換誘導体が含まれるので（疎水性が最大值に近づく につれ，共直線性が低くなり)， $\pi$ おび $\pi^{2}$ 項はともに大き く変化する. $\Delta \mathrm{B} 5$ の係数はほとんど変化していない，これ らのことから, 代謝阻害剂PBによって酸化代謝が抑制され ること，およびそのメカニズムが置換基の電子的性質に大き く依存することが推定できる。

酸化的代謝による活性の減少に関与している物理化学的性 質を調べることを目的に，表 1 の $\mathrm{pLD}_{50}(\mathrm{~PB})$ を独立変数に 用いて $\mathrm{pLD}_{50}$ (None) の回帰分析を行い，有意な式（3）が 得られた ${ }^{10)}$. 式 (3) の相関係数はそれほど高くないが, 代 謝による活性の低下には, 置換基の電子的性質が大きく関与 していることが示唆される.

$$
\begin{aligned}
\mathrm{pLD}_{50}(\text { None })= & 0.86( \pm 0.37) \mathrm{pLD}_{50}(\mathrm{~PB})+0.93( \pm 0.67) \sigma \\
& +0.17( \pm 2.35) \\
& n=16, \quad s=0.338, \quad r=0.822
\end{aligned}
$$

式（3）には，2,6- $\mathrm{Cl}_{2}$ 体と式（1）の誘導に用いた化合物が 含まれる. 式（3）において, $\mathrm{pLD}_{50}(\mathrm{~PB})$ の係数は 1 に近 く, $\mathrm{pLD}_{50}$ (None) の係数とほぼ 1 対 1 に対応する。また, 
表2. QSAR情報によって意図的に合成された化合物の活性と置換基定数

\begin{tabular}{|c|c|c|c|c|c|c|c|}
\hline \multicolumn{2}{|r|}{ 化合物 } & \multicolumn{3}{|c|}{$\mathrm{pLD}_{50}(\mathrm{~PB})$} & \multicolumn{3}{|c|}{ 置換基パラメーター } \\
\hline No. & 置換基 & 実測值 & $\begin{array}{l}\text { 計算值 } \\
\text { 式 }(10)\end{array}$ & 差 $^{a)}$ & $\pi$ & $\sigma_{\mathrm{I}}$ & $\Delta \mathrm{B} 5$ \\
\hline 30 & $\mathrm{O}\left(\mathrm{CH}_{2}\right)_{2} \mathrm{Ph}$ & 6.88 & 6.36 & 0.52 & 1.99 & 0.28 & 6.33 \\
\hline 31 & $\mathrm{O}\left(\mathrm{CH}_{2}\right)_{2} \mathrm{Ph}\left(4-\mathrm{OCH}_{3}\right)$ & 6.10 & 6.22 & -0.12 & 1.97 & 0.28 & 8.12 \\
\hline 32 & $\mathrm{O}\left(\mathrm{CH}_{2}\right)_{2} \mathrm{Ph}\left(2-\mathrm{CH}_{3}\right)$ & 6.66 & 6.64 & 0.02 & 2.55 & 0.28 & 6.33 \\
\hline 33 & $\mathrm{O}\left(\mathrm{CH}_{2}\right)_{2} \mathrm{Ph}\left(3-\mathrm{CH}_{3}\right)$ & 6.69 & 6.60 & 0.09 & 2.55 & 0.28 & 6.79 \\
\hline 34 & $\mathrm{O}\left(\mathrm{CH}_{2}\right)_{2} \mathrm{Ph}\left(4-\mathrm{CH}_{3}\right)$ & 6.48 & 6.56 & -0.08 & 2.55 & 0.28 & 7.41 \\
\hline 35 & $\mathrm{O}\left(\mathrm{CH}_{2}\right)_{2} \mathrm{Ph}(2-\mathrm{Cl})$ & 6.41 & 6.70 & -0.29 & 2.70 & 0.28 & 6.33 \\
\hline 36 & $\mathrm{O}\left(\mathrm{CH}_{2}\right)_{2} \mathrm{Ph}(3-\mathrm{Cl})$ & 6.86 & 6.65 & 0.21 & 2.70 & 0.28 & 6.91 \\
\hline 37 & $\mathrm{O}\left(\mathrm{CH}_{2}\right)_{2} \mathrm{Ph}(4-\mathrm{Cl})$ & 6.78 & 6.59 & 0.19 & 2.70 & 0.28 & 7.75 \\
\hline 38 & $\mathrm{O}\left(\mathrm{CH}_{2}\right)_{3} \mathrm{Ph}$ & 7.08 & 6.80 & 0.28 & 2.50 & 0.28 & 3.70 \\
\hline 39 & $\mathrm{O}\left(\mathrm{CH}_{2}\right)_{4} \mathrm{Ph}$ & 6.70 & 6.67 & 0.03 & 2.96 & 0.28 & 7.76 \\
\hline 40 & $\mathrm{Ph}$ & 6.89 & 6.56 & 0.33 & 1.96 & 0.12 & 2.11 \\
\hline 41 & $\mathrm{Ph}(4-\mathrm{Cl})$ & 7.02 & 6.92 & 0.10 & 2.67 & 0.15 & 2.11 \\
\hline 42 & $\mathrm{Ph}(4-\mathrm{Br})$ & 7.29 & 6.97 & 0.32 & 2.81 & 0.15 & 2.11 \\
\hline 43 & $\mathrm{SO}_{2} \mathrm{Ph}$ & 5.55 & 5.88 & -0.33 & 0.84 & 0.56 & 5.02 \\
\hline 44 & (E) $\mathrm{CH}=\mathrm{CHPh}$ & 6.78 & 6.80 & -0.02 & 2.58 & 0.06 & 2.38 \\
\hline 45 & (Z) $\mathrm{CH}=\mathrm{CHPh}$ & 6.46 & 6.53 & -0.07 & 2.58 & 0.06 & 6.07 \\
\hline 46 & $n$-Octyl & 6.68 & 6.80 & -0.12 & 4.02 & -0.04 & 6.39 \\
\hline 47 & $n$-Dodecyl & 6.41 & 6.30 & 0.11 & 6.05 & -0.04 & 9.27 \\
\hline 48 & $\mathrm{O}-2 \mathrm{Py}$ & 5.31 & 5.46 & -0.15 & 0.41 & 0.47 & 4.89 \\
\hline 49 & $\mathrm{O}-2 \mathrm{Py}\left(5-\mathrm{CF}_{3}\right)$ & 6.48 & 6.31 & 0.17 & 1.64 & 0.51 & 6.46 \\
\hline 50 & $\mathrm{O}-2 \mathrm{Py}(5-\mathrm{Cl})$ & 6.05 & 6.12 & -0.07 & 1.36 & 0.49 & 6.31 \\
\hline 51 & $\mathrm{O}-2 \mathrm{Py}(5-\mathrm{Br})$ & 6.01 & 6.23 & -0.22 & 1.55 & 0.49 & 6.61 \\
\hline 52 & $O-2 \mathrm{Py}(5-\mathrm{I})$ & 6.01 & 6.32 & -0.31 & 1.75 & 0.49 & 7.00 \\
\hline 53 & $\mathrm{O}-2 \mathrm{Py}\left(3,5-\mathrm{Cl}_{2}\right)$ & 6.58 & 6.59 & -0.01 & 2.11 & 0.51 & 6.31 \\
\hline 54 & $\mathrm{O}-2 \mathrm{Py}\left(3,5-\mathrm{Br}_{2}\right)$ & 6.52 & 6.76 & -0.24 & 2.53 & 0.51 & 6.61 \\
\hline 55 & $\mathrm{O}-2 \mathrm{Py}\left(3-\mathrm{CH}_{3}, 5-\mathrm{Br}\right)$ & 6.58 & 6.63 & -0.05 & 2.28 & 0.48 & 6.61 \\
\hline 56 & O-2Py (3-Cl, 5-COOEt) & 5.57 & 6.47 & -0.90 & 2.22 & 0.52 & 8.70 \\
\hline 57 & $\mathrm{O}-2 \mathrm{Py}\left(3-\mathrm{CF}_{3}, 5-\mathrm{Cl}\right)$ & 6.80 & 6.71 & 0.09 & 2.34 & 0.53 & 6.31 \\
\hline 58 & $\mathrm{O}-2 \mathrm{Py}\left(3-\mathrm{Cl}, 5-\mathrm{CF}_{3}\right)$ & 6.88 & 6.71 & 0.17 & 2.37 & 0.53 & 6.46 \\
\hline
\end{tabular}

a) 実測值から式（10）による計算値を差し引いた值.

擬変数項は有意でない， $\sigma$ の係数が正であるので, ベンゼ ン環の置換基の電子求引性が上昇するほど, 酸化的代謝が 抑えられ，活性が上昇することがわかる。また， $\mathrm{Cl}$ 体（3， diflubenzuron）の $\mathrm{pLD}_{50}$ (None) の值は最初の測定ではやや 低く現れた $\left(\mathrm{pLD}_{50}=6.01\right)$ が, 殺虫活性の測定を繰り返し たところ，表に示したように 6.50 という值が得られた。し たがって, 6.01 の值は, 測定操作の誤りによるものと判明し
た.このように，しばしば，回帰分析の結果が，供試化合物 の溶液の濃度調製が不正確であったり，化合物を取り間違え たりするなどの誤操作を指摘することがある.

式（2）の解析結果から, 活性強度のすぐれた化合物のデ ザインを試みた。まず，最適疎水性に対して 4.6 と計算され た。しかし, 表 1 かもも明らかなように, 本化合物セットで は, 置換基の $\pi$ 值が4.6を超えるものはなかった。したがっ 
て, 化合物の疎水性をさらに高めることによって, 活性が上 昇するものと期待できる. 疎水性を高めるための簡単な方 法として，アルキル鎖長の延長を考えた. 表1からも明らか なように，飽和アルキル鎖が長くなると $\Delta \mathrm{B} 5$ の值もそれと パラレルに大きくなって活性にとっては不利である. $\Delta \mathrm{B} 5$ の值をできるだけ小さく保つと同時に疎水性を高めること が望ましい，一つの方法は， B 環のパラ位にphenyl基を導 入し，環上にさらに置換基を導入して疎水性を高めること ができる，他に，表2に示されているような，benzyloxy基， phenethyloxy基, phenylpropyloxy基などの導入を考え，そ れらを合成し殺虫活性を測定した。これらの置換基のほと んどは, $\mathrm{Cl}$ に比べ, $\Delta \mathrm{B} 5$ および $\sigma_{\mathrm{I}}$ の值に関して活性上昇に とって必ずしも有利とは言えない，一方，疎水性 $\pi$ に関し ては, $\mathrm{Cl}$ よりは遥かに高く, 最適值も超えていない. 中で も，できるだけ $\Delta \mathrm{B} 5$ を小さくして疎水性を上げるように意 図して合成したphenyl（4-Br）体（42）は表2に挙げた化 合物の中で最も高い活性を示した. 大きな $\sigma_{I} と \pi$ 值をもつ置 換 benzyloxy 基や置換 pyridyloxy 基 ${ }^{20)}$ なども高い活性を示し た。また， $\Delta \mathrm{B} 5$ の効果をより明確にするために，幾何異性 の存在する styryl基 $(-\mathrm{CH}=\mathrm{CHPh})$ の導入を試みた. 予想 通り $E$ 型に比べて $\Delta \mathrm{B} 5$ の大きな $Z$ 型の活性は低く, 置換基の 結合軸からの最大幅が活性にとって重要であることが確認さ れた ${ }^{20)}$.

新たに合成した2,6- $\mathrm{F}_{2}$-benzoyl化合物 [B環para置換基： $\mathrm{O}\left(\mathrm{CH}_{2}\right)_{2} \mathrm{Ph}\left(\right.$ 30), O $\left(\mathrm{CH}_{2}\right)_{3} \mathrm{Ph}(\mathbf{3 8}), \mathrm{O}\left(\mathrm{CH}_{2}\right)_{4} \mathrm{Ph}($ 39), $\mathrm{Ph}$ (40), $\mathrm{SO}_{2} \mathrm{Ph}(43), \mathrm{CH}=\mathrm{CHPh}(44,45), n$-octyl (46), $n$-dodecyl (47)，O-2-Py（48）および芳香環が $\mathrm{Cl}, \mathrm{Br}, \mathrm{I}$, $\mathrm{CF}_{3}, \mathrm{OMe}, \mathrm{Me}, \mathrm{COOEt}$ な゙で置換されたもの（31-37, 41，42，49-58）を含めて, 再度 QSAR解析を行い, 式 (4) が得られた ${ }^{20)}$.

$$
\begin{aligned}
\mathrm{pLD}_{50}(\mathrm{~PB})= & 0.94( \pm 0.48) \sigma_{\mathrm{I}}+1.24( \pm 0.23) \pi \\
& -0.13( \pm 0.04) \pi^{2}-0.14( \pm 0.05) \Delta \mathrm{B} 5 \\
& +4.97( \pm 0.31) \\
n= & 53, \quad s=0.293, \quad r=0.860 ; \quad \pi_{\mathrm{opt}}=4.77
\end{aligned}
$$

式（4）の結果は， $\Delta \mathrm{B} 5$ の係数が若干小さくなったもの の， $\sigma_{\mathrm{I}}$ の係数， $\pi$ の最適值（4.77）は式（2）で得られた值 （4.61）に近く, 式（2）が予測性の高いものであったことを 示している.QSAR式の誘導においてもう一つ注意すること は，置換基の変化にともなって同じょうなパターンで変化す るパラメーターを同時に用いてはいけない，すなわち，合成 設計あるいは化合物の選択においてパラメーター間に共直線 性（collinearity）があるような置換基だけを含むような化合 物セットの選択は避けなければならない。式（4）の誘導に 用いたパラメーター間の単純相関の值は表3 の通りである.

$\pi, \Delta \mathrm{B} 5, \sigma_{\mathrm{I}}$ の間の直線性は極めて低い. $\pi$ と $\pi^{2}$ の間に $\pi$ （opt）より小さい
表3. パラメーター間の単相関性

\begin{tabular}{lccc}
\hline & $\pi$ & $\pi^{2}$ & $\Delta \mathrm{B}_{5}$ \\
\hline$\pi^{2}$ & 0.836 & 1.000 & \\
$\Delta \mathrm{B}_{5}$ & 0.357 & 0.242 & 1.000 \\
$\sigma_{\mathrm{I}}$ & 0.135 & 0.155 & 0.008 \\
\hline
\end{tabular}

がある.しかし, 式（3)，(4)において, $\pi$ と $\pi^{2}$ の項はどち らも95\%信頼限界内で有意である.さらに殺虫活性を向上 するため, 疎水性と電子求引性の高い置換基をpara位とと もにortho 抢よび meta位へ導入し, 多置換化合物の QSAR 解析を行うことにした。表 4 に用いた化合物の置換様式を示 した.

まずB環上の置換様式に従って化合物を分類し, 表 4 に示 した. 6位は無置換で2,3位が同時に置換された化合物（No. 92-107，112，113）の活性は相対的に高く2,6-位が共に置 換された化合物（No. 108-111）の活性は低い傾向にある. これらの化合物はいずれも ortho位に置換基をもつ，それぞ れのグループごとに特別な立体因子が関与するのかもしれな い．そこで，これらの化合物を除いた化合物群（No. 59-91） と無置換体（1）についてまず解析が行われて, 式（5）が導 かれた ${ }^{21)}$. $\sigma_{\mathrm{I}}$ パラメーターはその定義から, 置換基の位置 ごとに項の係数が変化する。 また, 立体効果も置換位置依存 性がある。したがって, ortho, meta, para置換体ごとに $\sigma_{\mathrm{I}}$ とEs項を分けて解析を行った．疎水性 $\Sigma \pi$ パラメーターは相 当する多置換アセトアニリドの $\log P$ から算出したものであ $3^{16)}$.

$$
\begin{aligned}
\mathrm{pLD}_{50}(\mathrm{~PB})= & 0.29( \pm 0.22) \Sigma \pi+0.63( \pm 0.57) \sigma_{\mathrm{I}}^{\mathrm{o}} \\
& +0.62( \pm 0.45) \Sigma \sigma_{\mathrm{I}}^{\mathrm{m}}+0.69( \pm 0.51) \sigma_{\mathrm{I}}^{\mathrm{p}} \\
& -0.63( \pm 0.29) \Delta 5^{\circ}-0.43( \pm 0.28) \Delta \mathrm{B} 5^{m}(\mathrm{~S}) \\
& -0.35( \pm 0.15) \Delta \mathrm{B} 5^{m}(\mathrm{~L})+5.69( \pm 0.49) \\
& n=33, \quad s=0.278, \quad r=0.831
\end{aligned}
$$

ここで, 両方の meta位が, ともに置換された 3,5-ジ置換化 合物において，2個の meta置換基はそれぞれの立体的かさ 高さによって区別されるものと考え，小さい方をS大きい方 をLで表した。一方の meta位にしか置換基が存在しない場 合は，小さい方の “置換基”すなわち $\mathrm{H} の$ 值は 0 となる. 式 （5）において ortho, meta， para位置換基の $\sigma_{\mathrm{I}}$ 係数は 0.63 , 0.69 とほぼ等しく, $\Delta \mathrm{B} 5^{m}$ (S) と $\Delta \mathrm{B} 5^{m}$ (L) の係数も似 通っていることから，3位および5位の置換基効果は，ほぼ 共通していることがわかる。したがって全体としての電子効 果と立体効果は単純にそれぞれのパラメーターの算術和とし て表すことができ, 解析し直したところ, 式（6）が得られ $た^{16)}$. 
表4. 多置換ベンゾイルフェニルウレア類の殺虫活性

\begin{tabular}{|c|c|c|c|c|c|c|c|c|}
\hline \multicolumn{6}{|c|}{ 化合物 } & \multicolumn{3}{|c|}{$\mathrm{pLD}_{50}(\mathrm{~PB})$} \\
\hline No. & $\mathrm{Y}_{2}$ & $\mathrm{Y}_{3}$ & $\mathrm{Y}_{4}$ & $\mathrm{Y}_{5}$ & $\mathrm{Y}_{6}$ & 実測値 & $\begin{array}{l}\text { 計算值 } \\
\text { 式（10） }\end{array}$ & 差 $^{a}$ \\
\hline 59 & $\mathrm{~F}$ & $\mathrm{H}$ & $\mathrm{Cl}$ & $\mathrm{H}$ & $\mathrm{H}$ & 6.48 & 6.30 & 0.18 \\
\hline 60 & $\mathrm{Cl}$ & $\mathrm{H}$ & $\mathrm{Cl}$ & $\mathrm{H}$ & $\mathrm{H}$ & 5.77 & 5.86 & -0.09 \\
\hline 61 & $\mathrm{Br}$ & $\mathrm{H}$ & $n-\mathrm{Bu}$ & $\mathrm{H}$ & $\mathrm{H}$ & 5.71 & 5.95 & -0.24 \\
\hline 62 & $\mathrm{CF}_{3}$ & $\mathrm{H}$ & $\mathrm{Cl}$ & $\mathrm{H}$ & $\mathrm{H}$ & 5.28 & 5.24 & 0.04 \\
\hline 63 & $\mathrm{CH}_{3}$ & $\mathrm{H}$ & $\mathrm{Br}$ & $\mathrm{H}$ & $\mathrm{H}$ & 5.87 & 5.81 & 0.06 \\
\hline 64 & $\mathrm{CH}_{3}$ & $\mathrm{H}$ & $n-\mathrm{Bu}$ & $\mathrm{H}$ & $\mathrm{H}$ & 5.87 & 6.06 & -0.19 \\
\hline 65 & $\mathrm{OCH}_{3}$ & $\mathrm{H}$ & $\mathrm{Br}$ & $\mathrm{H}$ & $\mathrm{H}$ & 5.22 & 5.53 & -0.31 \\
\hline 66 & $\mathrm{~F}$ & $\mathrm{H}$ & $\mathrm{H}$ & $\mathrm{CF}_{3}$ & $\mathrm{H}$ & 5.92 & 5.80 & 0.12 \\
\hline 67 & $\mathrm{Cl}$ & $\mathrm{H}$ & $\mathrm{H}$ & $\mathrm{Cl}$ & $\mathrm{H}$ & 5.84 & 5.53 & 0.31 \\
\hline 68 & $\mathrm{H}$ & $\mathrm{Cl}$ & $\mathrm{Cl}$ & $\mathrm{H}$ & $\mathrm{H}$ & 6.79 & 6.72 & 0.07 \\
\hline 69 & $\mathrm{H}$ & $\mathrm{Br}$ & $n-\mathrm{Bu}$ & $\mathrm{H}$ & $\mathrm{H}$ & 6.50 & 6.67 & -0.17 \\
\hline 70 & $\mathrm{H}$ & $\mathrm{CF}_{3}$ & $\mathrm{~F}$ & $\mathrm{H}$ & $\mathrm{H}$ & 5.98 & 6.13 & -0.15 \\
\hline 71 & $\mathrm{H}$ & $\mathrm{CF}_{3}$ & $\mathrm{Cl}$ & $\mathrm{H}$ & $\mathrm{H}$ & 6.78 & 6.46 & 0.32 \\
\hline 72 & $\mathrm{H}$ & $\mathrm{OCF}_{3}$ & $\mathrm{Br}$ & $\mathrm{H}$ & $\mathrm{H}$ & 6.02 & 5.97 & 0.05 \\
\hline 73 & $\mathrm{H}$ & $\mathrm{CH}_{3}$ & $\mathrm{Cl}$ & $\mathrm{H}$ & $\mathrm{H}$ & 5.62 & 6.03 & -0.41 \\
\hline 74 & $\mathrm{H}$ & $\mathrm{CH}_{3}$ & $\mathrm{Br}$ & $\mathrm{H}$ & $\mathrm{H}$ & 5.97 & 6.18 & -0.21 \\
\hline 75 & $\mathrm{H}$ & $\mathrm{CH}_{3}$ & $n-\mathrm{Bu}$ & $\mathrm{H}$ & $\mathrm{H}$ & 5.98 & 6.15 & -0.17 \\
\hline 76 & $\mathrm{H}$ & $\mathrm{C}_{2} \mathrm{H}_{5}$ & $\mathrm{Br}$ & $\mathrm{H}$ & $\mathrm{H}$ & 5.48 & 5.93 & -0.45 \\
\hline 77 & $\mathrm{H}$ & $\mathrm{Cl}$ & $\mathrm{H}$ & $\mathrm{Cl}$ & $\mathrm{H}$ & 6.20 & 6.48 & -0.28 \\
\hline 78 & $\mathrm{H}$ & $\mathrm{CF}_{3}$ & $\mathrm{H}$ & $\mathrm{CF}_{3}$ & $\mathrm{H}$ & 5.48 & 5.87 & -0.39 \\
\hline 79 & $\mathrm{~F}$ & $\mathrm{H}$ & $\mathrm{F}$ & $\mathrm{CF}_{3}$ & $\mathrm{H}$ & 6.20 & 6.17 & 0.03 \\
\hline 80 & $\mathrm{~F}$ & $\mathrm{H}$ & $\mathrm{F}$ & $\mathrm{OCF}_{3}$ & $\mathrm{H}$ & 5.89 & 5.78 & 0.11 \\
\hline 81 & $\mathrm{~F}$ & $\mathrm{H}$ & $\mathrm{Cl}$ & $\mathrm{CF}_{3}$ & $\mathrm{H}$ & 6.57 & 6.54 & 0.03 \\
\hline 82 & $\mathrm{~F}$ & $\mathrm{H}$ & $\mathrm{Cl}$ & $O-i-\operatorname{Pr}$ & $\mathrm{H}$ & 5.33 & 5.49 & -0.16 \\
\hline 83 & $\mathrm{~F}$ & $\mathrm{H}$ & $\mathrm{Cl}$ & $O$-allyl & $\mathrm{H}$ & 5.67 & 5.45 & 0.22 \\
\hline 84 & $\mathrm{~F}$ & $\mathrm{H}$ & $\mathrm{Cl}$ & $O$-propargyl & $\mathrm{H}$ & 5.73 & 5.71 & 0.02 \\
\hline 85 & $\mathrm{~F}$ & $\mathrm{H}$ & $\mathrm{Br}$ & $\mathrm{CF}_{3}$ & $\mathrm{H}$ & 6.75 & 6.61 & 0.14 \\
\hline 86 & $\mathrm{~F}$ & $\mathrm{H}$ & $\mathrm{Br}$ & $\mathrm{OCF}_{3}$ & $\mathrm{H}$ & 6.45 & 6.14 & 0.31 \\
\hline 87 & $\mathrm{Cl}$ & $\mathrm{H}$ & $\mathrm{Cl}$ & $\mathrm{CF}_{3}$ & $\mathrm{H}$ & 6.00 & 6.00 & 0.00 \\
\hline 88 & $\mathrm{H}$ & $\mathrm{Cl}$ & $\mathrm{Cl}$ & $\mathrm{Cl}$ & $\mathrm{H}$ & 6.55 & 6.98 & -0.43 \\
\hline 89 & $\mathrm{H}$ & $\mathrm{CF}_{3}$ & $\mathrm{Br}$ & $\mathrm{CF}_{3}$ & $\mathrm{H}$ & 6.14 & 6.34 & -0.20 \\
\hline 90 & $\mathrm{H}$ & $\mathrm{CH}_{3}$ & $\mathrm{Br}$ & $\mathrm{CH}_{3}$ & $\mathrm{H}$ & 6.29 & 5.94 & 0.35 \\
\hline 91 & $\mathrm{H}$ & $\mathrm{CH}_{3}$ & $\mathrm{CH}_{3}$ & $\mathrm{CH}_{3}$ & $\mathrm{H}$ & 5.46 & 5.18 & 0.28 \\
\hline
\end{tabular}


表4. 続き

\begin{tabular}{|c|c|c|c|c|c|c|c|c|}
\hline \multicolumn{6}{|c|}{ 化合物 } & \multicolumn{3}{|c|}{$\mathrm{pLD}_{50}(\mathrm{~PB})$} \\
\hline No. & $\mathrm{Y}_{2}$ & $\mathrm{Y}_{3}$ & $\mathrm{Y}_{4}$ & $\mathrm{Y}_{5}$ & $\mathrm{Y}_{6}$ & 実測值 & $\begin{array}{l}\text { 計算值 } \\
\text { 式 (10) }\end{array}$ & 差 $^{a)}$ \\
\hline 92 & $\mathrm{~F}$ & $\mathrm{Cl}$ & $\mathrm{H}$ & $\mathrm{H}$ & $\mathrm{H}$ & 6.14 & 6.06 & 0.08 \\
\hline 93 & $\mathrm{Cl}$ & $\mathrm{Cl}$ & $\mathrm{H}$ & $\mathrm{H}$ & $\mathrm{H}$ & 6.30 & 6.32 & -0.02 \\
\hline 94 & $\mathrm{CH}_{3}$ & $\mathrm{Cl}$ & $\mathrm{H}$ & $\mathrm{H}$ & $\mathrm{H}$ & 6.03 & 5.87 & 0.16 \\
\hline 95 & $\mathrm{CH}_{3}$ & $\mathrm{CH}_{3}$ & $\mathrm{H}$ & $\mathrm{H}$ & $\mathrm{H}$ & 4.94 & 5.11 & -0.17 \\
\hline 96 & $\mathrm{~F}$ & $\mathrm{Cl}$ & $\mathrm{Br}$ & $\mathrm{H}$ & $\mathrm{H}$ & 6.87 & 7.02 & -0.15 \\
\hline 97 & $\mathrm{Cl}$ & $\mathrm{Cl}$ & $\mathrm{Cl}$ & $\mathrm{H}$ & $\mathrm{H}$ & 6.83 & 7.09 & -0.26 \\
\hline 98 & $\mathrm{Cl}$ & $\mathrm{CH}_{3}$ & $\mathrm{Br}$ & $\mathrm{H}$ & $\mathrm{H}$ & 6.29 & 6.64 & -0.35 \\
\hline 99 & $\mathrm{CH}_{3}$ & $\mathrm{Cl}$ & $\mathrm{Br}$ & $\mathrm{H}$ & $\mathrm{H}$ & 6.66 & 6.73 & -0.07 \\
\hline 100 & $\mathrm{~F}$ & $\mathrm{CF}_{3}$ & $\mathrm{H}$ & $\mathrm{Cl}$ & $\mathrm{H}$ & 6.48 & 6.51 & -0.03 \\
\hline 101 & $\mathrm{Cl}$ & $\mathrm{CF}_{3}$ & $\mathrm{H}$ & $\mathrm{F}$ & $\mathrm{H}$ & 6.93 & 6.75 & 0.18 \\
\hline 102 & $\mathrm{Cl}$ & $\mathrm{CF}_{3}$ & $\mathrm{H}$ & $\mathrm{Cl}$ & $\mathrm{H}$ & 6.94 & 6.72 & 0.22 \\
\hline 103 & $\mathrm{Cl}$ & $\mathrm{CF}_{3}$ & $\mathrm{H}$ & $\mathrm{Br}$ & $\mathrm{H}$ & 6.86 & 6.72 & 0.14 \\
\hline 104 & $\mathrm{Br}$ & $\mathrm{CF}_{3}$ & $\mathrm{H}$ & $\mathrm{Cl}$ & $\mathrm{H}$ & 6.79 & 6.78 & 0.01 \\
\hline 105 & $\mathrm{Br}$ & $\mathrm{CF}_{3}$ & $\mathrm{H}$ & $\mathrm{CF}_{3}$ & $\mathrm{H}$ & 5.41 & 5.59 & -0.18 \\
\hline 106 & $\mathrm{Cl}$ & $\mathrm{Cl}$ & $\mathrm{H}$ & $\mathrm{CF}_{3}$ & $\mathrm{H}$ & 5.82 & 5.85 & -0.03 \\
\hline 107 & $\mathrm{Br}$ & $\mathrm{Cl}$ & $\mathrm{H}$ & $\mathrm{Cl}$ & $\mathrm{H}$ & 6.41 & 6.02 & 0.39 \\
\hline 108 & $\mathrm{~F}$ & $\mathrm{H}$ & $\mathrm{Br}$ & $\mathrm{H}$ & $\mathrm{F}$ & 5.62 & 6.46 & -0.84 \\
\hline 109 & $\mathrm{Br}$ & $\mathrm{CF}_{3}$ & $\mathrm{H}$ & $\mathrm{H}$ & $\mathrm{F}$ & $<5.00(7 \%)$ & 6.48 & \\
\hline 110 & $\mathrm{CH}_{3}$ & $\mathrm{H}$ & $\mathrm{Br}$ & $\mathrm{H}$ & $\mathrm{CH}_{3}$ & $<5.00(19 \%)$ & 5.88 & \\
\hline 111 & $\mathrm{Br}$ & $\mathrm{CF}_{3}$ & $\mathrm{Br}$ & $\mathrm{H}$ & $\mathrm{F}$ & $<5.00(7 \%)$ & 7.25 & \\
\hline 112 & $\mathrm{~F}$ & $\mathrm{Cl}$ & $\mathrm{F}$ & $\mathrm{Cl}$ & $\mathrm{H}$ & & 6.95 & -0.22 \\
\hline 113 & $\mathrm{Cl}$ & $\mathrm{Cl}$ & $\mathrm{Cl}$ & $\mathrm{Cl}$ & $\mathrm{H}$ & & 6.83 & -0.38 \\
\hline
\end{tabular}

a) 実測值から式（10）による計算値を差し引いた值.

$$
\begin{aligned}
\mathrm{pLD}_{50}(\mathrm{~PB})= & 0.32( \pm 0.16) \Sigma \pi+0.68( \pm 0.23) \Sigma \sigma_{\mathrm{I}} \\
& -0.41( \pm 0.12) \Sigma \Delta \mathrm{B} 5^{m}-0.76( \pm 0.25) \Delta \mathrm{B} 5^{\circ} \\
& -1.00( \pm 0.76) \pi_{(2)}+5.68( \pm 0.39) \\
& n=33, \quad s=0.240, \quad r=0.867
\end{aligned}
$$

式（6）においては， $\Delta B 5^{p}$ は有意とはならなかった。また, 式（6）の誘導の過程で, ortho位置換基に特異的な疎水性パ ラメーター $\pi_{(2)}$ 項が有意となる. すなわち, ortho位に疎水 性置換基が存在すると活性が大きく低下することがわかる. 式（5)，（6）において， $\Sigma \pi$ （置換基の $\pi$ の和）の自乗項が有 意となっていないが，これは解析に用いた化合物の疎水性が 比較的低いところに偏って分布していることに起因する.

次に, 式（5）および（6）において除外した化合物の活性 を式（6）によって計算したところ，2,3-位がともに置換さ れた化合物（2,3-，2,3,4-，2,3,5-，2,3,4,5-置換体）のほとん
どは，それらの計算值が実測值よりも高かった．種々の考察 を経て,このことは, 式（6）では式（4）に含まれるモノオ ルト置換体では置換基の位置が 2 位であるとする定義に引き ずられ，2位と6位の区別なしに有意となっている立体効果 $\left(\Delta \mathrm{B}^{\circ}\right)$ が，これらの化合物では他の位置の置換基の影響を 受け区別することが必要であることを示唆しているとした. そして, 図3に示すように, 二つの meta置換基の相対的な 大きさの違いによって2位と6位が区別されると考えた。す なわち, 大きいほうの meta置換基が常に5位にくるように フェニル側ベンゼン環（B環）を 180 度回転した構造をとる と仮定した。例えば，2-F-3-Cl-4-Brは4-Br-5-Cl-6-Fとし て, 2-F-3- $\mathrm{CF}_{3}-5-\mathrm{Cl}$ は3-Cl-5- $\mathrm{CF}_{3}-6-\mathrm{F}$ 体として挙動すると 考えた。このような条件を設けてすべての化合物の活性を解 析したところ, 式（7）が得られた. 


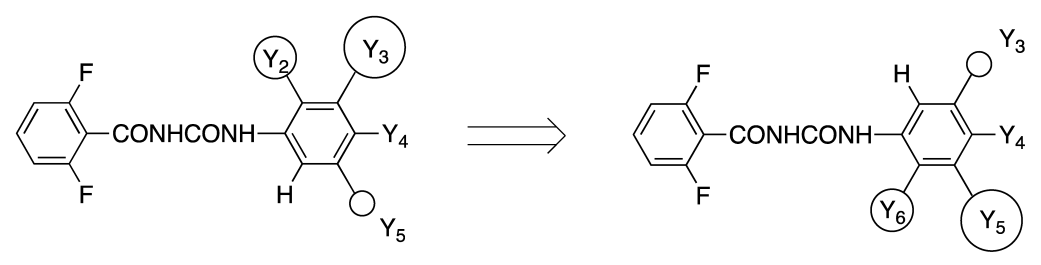

図3. meta置換基の相対的大きさによる2位および6位の区別

$$
\begin{aligned}
& \mathrm{pLD}_{50}(\mathrm{~PB})= 1.02( \pm 0.44) \Sigma \pi-0.18( \pm 0.12)(\Sigma \pi)^{2} \\
&+0.68( \pm 0.16) \Sigma \sigma_{\mathrm{I}}-0.34( \pm 0.09) \Sigma \Delta \mathrm{B} 5^{m} \\
&-0.72( \pm 0.59) \pi_{(2)}-0.57( \pm 0.18) \Delta \mathrm{B} 5^{(2)} \\
&+0.34( \pm 0.22) \Delta \mathrm{B} 5^{(6)}+4.93( \pm 0.40) \\
& n=51, \quad s=0.232, \quad r=0.908, \quad \pi_{\mathrm{opt}}=2.83
\end{aligned}
$$

式（7）においては, 式（6）で用いたパラメーター項に加 えて, $\Sigma \pi$ の自乗項, 上記のように定義された6位の置換基 の立体パラメーター $\Delta \mathrm{B} 5{ }^{(6)}$ 項が有意となった. $\Sigma \pi$ の自乗項 の存在に関しては, 式（2）と（4）から判断しても妥当であ

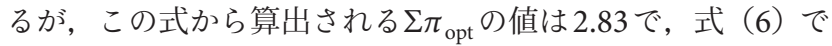
得られた值 $\left(\pi_{\mathrm{opt}}=4.77\right)$ に比べるとかなり小さく, 最適值 の確認にはなお検討が必要である。一方, 正の係数をもつ $\Delta \mathrm{B} 5{ }^{(6)}$ 項は, 置換基の幅が広いほど活性が高くなることを 表す。オルト置換基の立体効果には特異的な因子が加わっ ている可能性が予測された。そこで，オルト置換基がメタ 置換基と隣り合わせになっている2,3-および5,6-置換体に対 して， $\Delta \mathrm{B} 5{ }^{(6)}$ の代わりにオルト置換基とメタ置換基の立体 パラメーターの積, $\Delta \mathrm{B} 5^{\circ} \cdot \Delta \mathrm{B} 5^{m}$ を用いて解析を行い, 式 (8) か薄かれた ${ }^{21)}$.

$$
\begin{aligned}
& \mathrm{pLD}_{50}(\mathrm{~PB})= 0.97( \pm 0.41) \sum \pi-0.17( \pm 0.11)\left(\sum \pi\right)^{2} \\
&+0.66( \pm 0.15) \Sigma \sigma_{\mathrm{I}}-0.67( \pm 0.15) \Delta \mathrm{B} 5^{(2)} \\
&-0.97( \pm 0.59) \pi_{(2)}-0.38( \pm 0.09) \Delta \mathrm{B} 5^{m} \\
&+0.28( \pm 0.15)^{\circ} \Delta \mathrm{B} 5^{o} \cdot \Delta \mathrm{B} 5^{m}+5.07( \pm 0.35) \\
& n=51, \quad s=0.222, \quad r=0.917 ; \quad \pi_{\mathrm{opt}}=2.85
\end{aligned}
$$

式（8）は式（7）より良好な相関関係を与え， $\Delta \mathrm{B} 5^{\circ} \cdot \Delta \mathrm{B} 5^{m}$ の項は有意となる。すなわち, $\Delta \mathrm{B} 5$ の積の項は, 互いに隣 接する置換基の一方の効果が他方の効果を積の形で “支え 合う”いわゆる buttressing effectに基づく“立体促進的効 果” 22) の存在を示唆する.

式（8）においては, B環para位置換基の項 $\Delta \mathrm{B} 5^{\mathrm{p}}$ は有意 とならなかった。式（2）および（4）では有意であったが, 式（18）では寄与は小さく, 置換基の種類が多くなるとと もに有意性が失われたものと考えられる。最終的に式（4） と式（8）の結果を合わせて解析を行い, 式（9）を導いた.

$$
\begin{aligned}
\mathrm{pLD}_{50}(\mathrm{~PB})= & 1.02( \pm 0.16) \sum \pi-0.12( \pm 0.03)\left(\sum \pi\right)^{2} \\
& +0.57( \pm 0.15) \sum \sigma_{\mathrm{I}}-0.72( \pm 0.15) \Delta \mathrm{B} 5^{(2)} \\
& -1.23( \pm 0.62) \pi_{(2)}+0.25( \pm 0.16) \Delta \mathrm{B} 5^{o} \cdot \Delta \mathrm{B} 5^{m} \\
& -0.50( \pm 0.08) \Sigma \Delta \mathrm{B} 5^{m}-0.09( \pm 0.03) \Delta \mathrm{B} 5^{p} \\
& +5.20( \pm 0.19) \\
n= & 103, \quad s=0.245, \quad r=0.896, \quad \pi_{\mathrm{opt}}=4.25
\end{aligned}
$$

\begin{tabular}{|c|c|c|c|c|c|c|c|}
\hline \multirow[b]{2}{*}{ No. } & \multirow[b]{2}{*}{$\mathrm{Y}_{2}$} & \multirow[b]{2}{*}{$\mathrm{Y}_{3}$} & \multirow[b]{2}{*}{$\mathrm{Y}_{5}$} & \multirow[b]{2}{*}{$\mathrm{Y}_{6}$} & \multicolumn{2}{|c|}{$\mathrm{pLD}_{50}(\mathrm{~PB})$} & \multirow[b]{2}{*}{ 差 $^{a)}$} \\
\hline & & & & & 実測值 & $\begin{array}{l}\text { 計算值 } \\
\text { 式 }(10)\end{array}$ & \\
\hline 114 & $\mathrm{H}$ & $\mathrm{Cl}$ & $\mathrm{Cl}$ & $\mathrm{H}$ & 7.13 & 6.90 & 0.23 \\
\hline 115 & $\mathrm{Cl}$ & $\mathrm{Cl}$ & $\mathrm{H}$ & $\mathrm{H}$ & 6.89 & 6.57 & 0.32 \\
\hline 116 & $\mathrm{H}$ & $\mathrm{Cl}$ & $\mathrm{H}$ & $\mathrm{H}$ & 6.73 & 6.79 & -0.06 \\
\hline 117 & $\mathrm{CH}_{3}$ & $\mathrm{H}$ & $\mathrm{H}$ & $\mathrm{H}$ & 6.40 & 6.07 & 0.33 \\
\hline 118 & $\mathrm{CH}_{3}$ & $\mathrm{H}$ & $\mathrm{CH}_{3}$ & $\mathrm{H}$ & 6.54 & 6.14 & 0.40 \\
\hline
\end{tabular}

式（8）に比べると，相関関係は若干低下したが，8個のパ ラメーターで103個の化合物の活性を説明することができ, 最適の疎水性 $\left(\pi_{\mathrm{opt}}\right)$ も 4.25 で, パラ置換体の解析で得られ た值に近い值となった。

最後に，かなり複雑な構造をもった chlorfluazuron類縁体 （114-118）（表5）の活性を測定し, 式（9）の妥当性の検証 を試みた。図3の定義に従うとNo. 115 と116は，それぞれ 3,4,6-と4,5-置換と考える必要があるが, そのような置換位

表5. Chlorfluazuron型化合物の活性

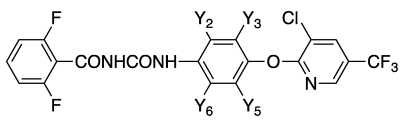

a) 実測值から式（10）による計算値を差し引いた值. 


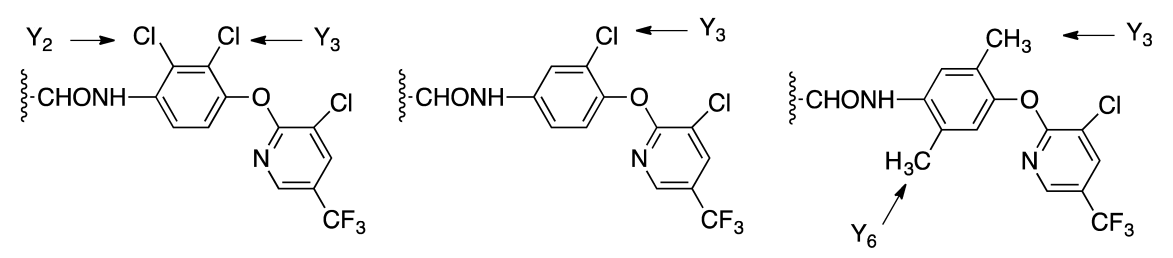

図4. 置換pyridyloxy基をpara位にもった多置換化合物の置換位置

表6. 式（10）の誘導に用いたパラメーター間の単相関性

\begin{tabular}{|c|c|c|c|c|c|c|c|}
\hline & $\Sigma \pi$ & $(\Sigma \pi)^{2}$ & $\Sigma \sigma_{\mathrm{I}}$ & $\Sigma \Delta \mathrm{B} 5^{m}$ & $\Delta \mathrm{B} 5^{p}$ & $\Delta \mathrm{B} 5^{(2)}$ & $\Delta \mathrm{B} 5^{o} \cdot \Delta \mathrm{B} 5^{n}$ \\
\hline$(\Sigma \pi)^{2}$ & 0.851 & & & & & & \\
\hline$\Sigma \sigma_{\mathrm{I}}$ & 0.007 & 0.020 & & & & & \\
\hline$\Sigma \Delta \mathrm{B} 5^{m}$ & 0.002 & 0.001 & 0.453 & & & & \\
\hline$\Delta \mathrm{B} 5^{p}$ & 0.266 & 0.239 & 0.225 & 0.321 & & & \\
\hline$\Delta \mathrm{B} 5^{(2)}$ & 0.028 & 0.023 & 0.100 & 0.009 & 0.048 & & \\
\hline$\Delta \mathrm{B} 5^{o} \cdot \Delta \mathrm{B} 5^{m}$ & 0.003 & 0.005 & 0.182 & 0.173 & 0.131 & 0.006 & \\
\hline$\pi_{(2)}$ & 0.042 & 0.027 & 0.000 & 0.000 & 0.003 & 0.092 & 0.059 \\
\hline
\end{tabular}

置設定では，これらは式（9）で予測することはできなかっ た.そこで, 図3で示した置換位置の設定を再考察した．表 5 に示されている5個の化合物において, 図3の方式に従う と, 小さい方の meta置換基はHで, これを3位に, また通 常の定義による3位の置換基をすべて 5 位に配置せねばなら ない.しかし, 図4に示した配置の方が, 式（9）による計 算值とよく一致することがわかった。これは, 2-Cl-4- $\mathrm{CF}_{3}-$ Pyridyloxy基が立体的に嵩高いために，5位置換基が配置さ れるはずの領域まで占有することによるものと推察されよ う。図4のように置換位置を設定し，これら pyridyloxy化合 物を含めて，最終的に式（10）を得た.

$$
\begin{aligned}
& \mathrm{pLD}_{50}(\mathrm{~PB})= 1.01( \pm 0.16) \Sigma \pi-0.12( \pm 0.03)(\Sigma \pi)^{2} \\
&+0.59( \pm 0.14) \Sigma \sigma_{\mathrm{I}}-0.68( \pm 0.15) \Delta \mathrm{B}_{5}^{(2)} \\
&-1.27( \pm 0.60) \pi_{(2)}+0.27( \pm 0.16) \Delta \mathrm{B}_{5}^{o} \cdot \Delta \mathrm{B}_{5}^{m} \\
&-0.49( \pm 0.08) \Delta \mathrm{B}_{5}^{m}-0.07( \pm 0.03) \Delta \mathrm{B}_{5}^{p} \\
&+5.15( \pm 0.19) \\
& n=108, \quad s=0.250, \quad r=0.890 ; \quad \pi_{\mathrm{opt}}=4.25
\end{aligned}
$$

式（10）において, ベンゼン環に 4 程度の疎水性をもち誘 起的電子求引基の高い置換基が導入されると活性の上昇す ることがわかる。一方立体パラメーター $\Delta$ B 5 の係数すべて マイナスであることから活性は, ortho, meta, paraのす心゙ ての位置で嵩高い置換基の導入は不利である。ここで, 測 定した化合物の中で，3個の化合物 4-Et（7), O-2Py（3-Cl, 5-COOEt) (56)，2,6- $\mathrm{F}_{2}-4-\mathrm{Br}$ (No. 108）の活性は, 式（10） によって予測することはできなかった。化合物 56 におい ては加水分解が，化合物 108 ば, 2,6-ジ置換様式を含む 本化合物に特異的な立体効果の関与が考えられる. 化合物
7 (4-Et) 体に関しては，その理由は不明である。最終的な QSAR式（10）で用いられたパラメーター間の共直線性を表 6に示す。

以上，フェニル置換体に関しては，モノ置換体である para 体から，多置換体に亘る合計 108 個の誘導体の活性を 8 個の パラメーターで解析することができた ${ }^{21)}$.

\section{2. ベンゾイル側}

Diflubenzuron型化合物（図 $2 ; Y_{\mathrm{n}}=4-\mathrm{Cl}$ ）のベンゾイル 側ベンゼン環 ortho, meta, para位に置換基（F, Cl, Br, $\mathrm{CH}_{3}, \mathrm{NO}_{2}$ ) を導入して活性を調べたが, meta, para置換体 においては活性指標を求めることができなかった。そこで, ortho 置換体だけを用い, ortho 位の置換基効果の解析を行っ た。

表7に示したように, 片方の ortho位にハロゲン, アルキ ル, アルコキシ, ニトロ, シアノの置換基の導入を行った が, 置換基が $\mathrm{CH}_{3}$ から $\mathrm{C}_{2} \mathrm{H}_{5}$ に，あるいは $\mathrm{OCH}_{3}$ に変わる だけで活性值を求めることができなくなった. $\mathrm{OC}_{2} \mathrm{H}_{5}, \mathrm{~N}$ $\left(\mathrm{CH}_{3}\right)_{2}, i-\mathrm{Pr}, \mathrm{Ph}$ 導入した化合物においても活性は見い だされなかった. 化合物によっては酸化や加水分解代謝を 受けやすく活性を評価できない場合があって, 共力剂の存 在下でのみ活性值が得られることはすでに述べた。表7か らわかるように，ベンゾイル側が置換されたBPU類におい ても， $\mathrm{LD}_{50}$ 值が得られなかった化合物 No. 128, 130, 140 の活性は, PB併用下で求めることができた. 加水分解代謝 阻害剂DEFの併用下では，これら化合物の活性上昇は認め られなかった。一方, PB添加条件下でも活性を測定できな かった化合物No. 136 は, DEFを用いることによって, 活性 
表7. ベンゾイル部に様々な置換基をもったBPU類の活性と置換基パラメーター

\begin{tabular}{|c|c|c|c|c|c|c|c|c|c|c|c|c|}
\hline \multirow{2}{*}{ No. } & \multirow{2}{*}{$\mathrm{X}_{1}$} & \multirow{2}{*}{$\mathrm{X}_{2}$} & \multicolumn{3}{|c|}{$\mathrm{pLD}_{50}{ }^{a)}$} & \multirow{2}{*}{$\begin{array}{l}\text { 計算值 } \\
\text { 式（13） }\end{array}$} & \multirow{2}{*}{ 差 $^{b)}$} & \multicolumn{5}{|c|}{ 置換基パラメーター } \\
\hline & & & None & DEF & $\mathrm{PB}$ & & & $\pi$ & Es & $\sigma$ & $\sigma_{\mathrm{I}}$ & $\sigma^{\#}$ \\
\hline 119 & $\mathrm{H}$ & $\mathrm{H}$ & $<5.60(0 \%)$ & $<5.60(0 \%)$ & $<5.60(0 \%)$ & 6.67 & & 0.00 & 0.00 & 0.00 & 0.00 & 0.00 \\
\hline 3 & $\mathrm{~F}$ & $\mathrm{~F}$ & 6.50 & 6.58 & 6.64 & 6.45 & 0.19 & -0.39 & -0.60 & 0.12 & 1.08 & 1.08 \\
\hline 120 & $\mathrm{Cl}$ & $\mathrm{Cl}$ & 5.60 & 5.49 & 5.69 & 5.70 & -0.01 & 0.13 & -1.88 & 0.46 & 0.94 & 0.94 \\
\hline 121 & $\mathrm{Br}$ & $\mathrm{Br}$ & 5.36 & 5.45 & 5.36 & 5.62 & -0.26 & 0.36 & -2.16 & 0.46 & 0.94 & 0.94 \\
\hline 122 & $\mathrm{CH}_{3}$ & $\mathrm{CH}_{3}$ & 5.00 & 5.09 & 5.20 & 5.09 & 0.11 & 0.26 & -2.22 & -0.34 & -0.02 & -0.02 \\
\hline 123 & $\mathrm{~F}$ & $\mathrm{Cl}$ & 6.34 & 6.15 & 6.29 & 6.06 & 0.23 & -0.15 & -1.24 & 0.29 & 1.01 & 1.01 \\
\hline 124 & $\mathrm{OCH}_{3}$ & $\mathrm{OCH}_{3}$ & $<5.30(11 \%)$ & $<5.30(6 \%)$ & 5.79 & 5.84 & -0.05 & -0.86 & -0.76 & -0.54 & 0.60 & 0.60 \\
\hline 125 & $\mathrm{NO}_{2}$ & $\mathrm{CH}_{3}$ & 4.60 & 4.81 & 4.69 & 4.56 & 0.13 & -0.54 & -2.69 & 0.61 & 0.66 & 0.66 \\
\hline 126 & $\mathrm{Cl}$ & $\mathrm{CH}_{3}$ & 5.42 & 5.60 & 5.82 & 5.43 & 0.39 & 0.25 & -2.05 & 0.06 & 0.46 & 0.46 \\
\hline 127 & $\mathrm{NO}_{2}$ & $\mathrm{Cl}$ & 4.77 & 4.76 & 4.63 & 4.91 & -0.28 & -0.52 & -2.52 & 1.01 & 1.14 & 1.14 \\
\hline 128 & $\mathrm{~N}\left(\mathrm{CH}_{3}\right)_{2}$ & $\mathrm{~F}$ & $<4.78(0 \%)$ & $<4.78(0 \%)$ & 5.09 & 5.50 & -0.41 & -0.02 & -1.90 & -0.77 & 0.71 & 0.71 \\
\hline 129 & $\mathrm{Br}$ & $\mathrm{Cl}$ & 5.56 & 5.37 & 5.76 & 5.73 & 0.03 & 0.36 & -2.02 & 0.46 & 0.94 & 0.94 \\
\hline 130 & $\mathrm{~N}\left(\mathrm{CH}_{3}\right)_{2}$ & $\mathrm{Cl}$ & $<4.78(0 \%)$ & $<4.78(5 \%)$ & 5.33 & 5.11 & 0.22 & 0.21 & -2.54 & -0.60 & 0.64 & 0.64 \\
\hline 131 & $\mathrm{NO}_{2}$ & $\mathrm{OCH}_{3}$ & 5.47 & 5.36 & 5.36 & 5.05 & 0.31 & -0.90 & -1.96 & 0.51 & 0.97 & 0.97 \\
\hline 132 & $\mathrm{OCH}_{3}$ & $\mathrm{Cl}$ & 5.42 & 5.39 & 5.88 & 5.96 & -0.08 & -0.05 & -1.32 & -0.04 & 0.77 & 0.77 \\
\hline 133 & $\mathrm{Br}$ & $\mathrm{F}$ & 5.96 & 6.07 & 6.18 & 6.04 & 0.14 & -0.01 & -1.38 & 0.29 & 1.01 & 1.01 \\
\hline 134 & $\mathrm{NO}_{2}$ & $\mathrm{NO}_{2}$ & & $<5.30(0 \%)$ & $<5.30(0 \%)$ & 4.29 & & -0.89 & -3.16 & 1.56 & 1.34 & 1.34 \\
\hline 135 & $\mathrm{NO}_{2}$ & $\mathrm{Br}$ & & $<5.30(0 \%)$ & $<5.30(0 \%)$ & 4.90 & & -0.36 & -2.66 & 1.01 & 1.14 & 1.14 \\
\hline 136 & $\mathrm{~F}$ & $\mathrm{H}$ & $<5.30(5 \%)$ & 5.63 & $<5.30(0 \%)$ & 6.43 & & -0.05 & -0.30 & 0.06 & 0.54 & 0.06 \\
\hline 137 & $\mathrm{Cl}$ & $\mathrm{H}$ & 5.90 & 6.27 & 6.01 & 6.04 & -0.03 & 0.00 & -0.94 & 0.23 & 0.47 & 0.23 \\
\hline 138 & $\mathrm{Br}$ & $\mathrm{H}$ & 6.31 & 6.21 & 6.06 & 6.01 & 0.05 & 0.13 & -1.08 & 0.23 & 0.47 & 0.23 \\
\hline 139 & I & $\mathrm{H}$ & 5.68 & 5.73 & 5.44 & 5.85 & -0.41 & 0.29 & -1.38 & 0.18 & 0.40 & 0.18 \\
\hline 140 & $\mathrm{NO}_{2}$ & $\mathrm{H}$ & $<4.78(47 \%)$ & 5.04 & 4.99 & 5.34 & -0.35 & -0.76 & -1.58 & 0.78 & 0.67 & 0.78 \\
\hline 141 & $\mathrm{CH}_{3}$ & $\mathrm{H}$ & 5.85 & 5.99 & 5.88 & 5.80 & 0.08 & 0.12 & -1.11 & -0.17 & -0.01 & -0.17 \\
\hline 142 & $\mathrm{~N}\left(\mathrm{CH}_{3}\right)_{2}$ & $\mathrm{H}$ & & $<5.30(0 \%)$ & $<5.30(0 \%)$ & 5.05 & & -0.02 & -1.60 & -0.83 & 0.17 & -0.83 \\
\hline 143 & $\mathrm{C}_{2} \mathrm{H}_{5}$ & $\mathrm{H}$ & & $<5.60(0 \%)$ & $<5.30(0 \%)$ & 5.92 & & 0.53 & -1.28 & -0.15 & -0.01 & -0.15 \\
\hline 144 & $\mathrm{OCH}_{3}$ & $\mathrm{H}$ & $<5.30(5 \%)$ & $<5.30(0 \%)$ & $<5.60(0 \%)$ & 6.32 & & 0.11 & -0.38 & -0.27 & 0.30 & -0.27 \\
\hline 145 & $\mathrm{OC}_{2} \mathrm{H}_{5}$ & $\mathrm{H}$ & & & $<5.30(0 \%)$ & 6.44 & & 0.50 & -0.53 & -0.24 & 0.28 & -0.24 \\
\hline 146 & $\mathrm{CF}_{3}$ & $\mathrm{H}$ & & $<5.30(0 \%)$ & $<5.30(0 \%)$ & 5.11 & & 0.04 & -2.35 & 0.54 & 0.40 & 0.54 \\
\hline 147 & $\mathrm{CN}$ & $\mathrm{H}$ & & $<5.30(0 \%)$ & $<5.30(0 \%)$ & 6.31 & & -0.64 & -0.35 & 0.66 & 0.57 & 0.66 \\
\hline 148 & $\mathrm{SCH}_{3}$ & $\mathrm{H}$ & & $<5.60(0 \%)$ & $<5.60(0 \%)$ & 5.86 & & 0.07 & -1.09 & 0.00 & 0.30 & 0.00 \\
\hline 149 & $i-\operatorname{Pr}$ & $\mathrm{H}$ & & $<5.60(0 \%)$ & $<5.60(0 \%)$ & 5.80 & & 0.75 & -1.60 & -0.15 & 0.01 & -0.15 \\
\hline 150 & $\mathrm{Ph}$ & $\mathrm{H}$ & & $<5.30(0 \%)$ & $<5.60(0 \%)$ & 5.56 & & 0.90 & -2.10 & -0.01 & 0.12 & -0.01 \\
\hline
\end{tabular}

a) 空欄：活性未測定. $\left.{ }^{b}\right) \mathrm{PLD}_{50}(\mathrm{~PB})$ から式（13）による計算值を差し引いた值.

を求めることができ，この化合物は片方の ortho 位が立体的 に小さな Fで置換された化合物で，加水分解代謝を受けやす い構造であると考えた。このことから，無置換体（No. 119） は，2-F体（No. 136）よりさらに加水分解を受けやすい構造 で, $\mathrm{LD}_{50}$ 值を求めるに至らなかったと推察された. 理想的 にはPB と DEFを同時に用いて酸化と加水分解代謝を共に抑 えて，活性を評価するのが良いが，今回の殺虫試験では，両 方の代謝阻害剂を同時に用いることで，昆虫の成長がかなり 抑制されることから，どちらか一方の共力剤併用下で活性の 測定を行わざるを得なかった ${ }^{11)}$. 以上, 定性的な解析結果
を念頭において，ジ置換体 15 化合物についてQSAR解析を 行った。その結果は式（11）で表される.

$$
\begin{aligned}
& \mathrm{pLD}_{50}(\mathrm{~PB})= 0.83( \pm 0.40) \mathrm{E}_{\mathrm{s}}^{o}(\mathrm{~L})+0.87( \pm 0.53) \mathrm{E}_{\mathrm{s}}^{o}(\mathrm{~S}) \\
&+0.51( \pm 0.41) \pi+7.18( \pm 0.51) \\
& n=15, \quad s=0.265, \quad r=0.910
\end{aligned}
$$

式（11）において, $\mathrm{E}_{\mathrm{s}}^{o}$ は ortho 置換 benzamideの加水分解速 度から算出された立体パラメーター ${ }^{23)} て ゙, \mathrm{E}_{\mathrm{s}}^{o}(\mathrm{~L})$ は大きい 方の置換基, $\mathrm{E}_{\mathrm{s}}^{o}(\mathrm{~S})$ は小さい方の置換基に対するものであ る. $\pi$ は置換ベンズアミドの1-オクタノール/水系における 
表 8. パラメーター間の単相関性 $\left(r^{2}\right)$

\begin{tabular}{lccc}
\hline & $\Sigma \mathrm{E}_{\mathrm{s}}^{o}$ & $\pi$ & $\sigma^{\#}$ \\
\hline$\pi$ & 0.016 & 1.000 & \\
$\sigma^{\#}$ & 0.033 & 0.132 & 1.000 \\
\hline
\end{tabular}

分配係数（P）から算出した置換基の疎水性パラメーターで ある ${ }^{24)}$. 式（11）において $\mathrm{E}_{\mathrm{s}}^{o}(\mathrm{~L})$ と $\mathrm{E}_{\mathrm{s}}^{o}(\mathrm{~S})$ の係数がほぼ等 しいことから，それらの和を立体パラメーター $\Sigma \mathrm{E}_{\mathrm{s}}^{\mathrm{o}}$ として用 いて再度解析を行い, 式（12）を導いた。

$$
\begin{aligned}
\mathrm{pLD}_{50}(\mathrm{~PB})= & 0.84( \pm 0.24) \Sigma \mathrm{E}_{\mathrm{s}}^{o}+0.50( \pm 0.36) \pi \\
& +7.18( \pm 0.48) \\
n & =15, \quad s=0.253, \quad r=0.910
\end{aligned}
$$

次に活性の得られた $5 つ の$ ortho モノ置換体を加えて, 電子 的効果も合わせて再検討したところ，式（13）が得られた.

$$
\begin{aligned}
\mathrm{pLD}_{50}(\mathrm{~PB})= & 0.77( \pm 0.21) \Sigma \mathrm{E}_{\mathrm{s}}^{o}+0.59( \pm 0.33) \pi \\
& +0.44( \pm 0.36) \sigma^{\#}+6.67( \pm 0.39) \\
& n=20, \quad s=0.257, \quad r=0.895
\end{aligned}
$$

式（13）において， $\sigma^{\#}$ は orthoジ置換体に対しては $\Sigma \sigma_{\mathrm{I}}$ を, モノ置換体に対しては すなわち，両 ortho 位が置換された場合にベンゼン環はアミ ド結合面に対して垂直となり，ベンゼン環とカルボニル基と の間の共鳴効果が消失し, 誘起的電子求引性効果 $\left(\sigma_{\mathrm{I}}\right)$ だけ が有意となると考えられる。式（13）で用いられているパ ラメーター $\Sigma \mathrm{E}_{s}^{o}, \pi, \quad \sigma^{\#}$ の相関性は表 8 の通りで，それらの 共直線性は低いことが分かる。最終的なQSAR式（13）に おいて, $\mathrm{OCH}_{3}$ 体 (144)， OEt体（145）, $\mathrm{CN}$ 体（147）の 活性は予測できていないが，置換基ORに関しては，アミド $\mathrm{HN}-の$ 間で分子内水素結合が形成され，それが活性低下の 原因と考えられている ${ }^{26)}$.

式（13）の結果から，最も好ましいベンゾイル側置換基 として, かさ高さが比較的小さく, 疎水性で電子求引性の高 い2-F，2-Cl，2,6- $\mathrm{F}_{2}$, 置換体などが考えられる. 実際, 実 用されている化合物のベンゾイル側の置換基は大半が 2,6- $\mathrm{F}_{2}$ 体であるが, perfluron (2-F体), triflumuron（2- $\mathrm{Cl}$ 体）（図 1）などもある7).

\section{3. その他昆虫に対する殺虫活性のQSAR}

以上のように，二カメイチュウに対する殺虫活性のQSAR を詳細に解説したが, その中で, 加水分解代謝阻害剂や酸化 代謝阻害剂を用いることによって活性が大きく上昇する化合 物のあることを述べた，QSAR解析より，電子供与性基で置 換されている化合物は, 酸化されやすく, 逆に $\mathrm{NO}_{2}$ 基のよ うな電子求引性の強い置換基で置換された化合物は加水分解
されやすいことが示された。すなわち，二カメイチュウに対 しては, PB併用下で求めた活性の QSAR解析を, 共力剂の ない条件で測定した活性のQSAR解析を比較すると, 電子 的パラメーターの寄与が著しく増加することがわかった。

ついで，二カメイチュウに対する殺虫活性の解析結果を 他の昆虫（幼虫）に関する結果と比較することによって， QSARにおける代謝の意義をさらに明確にしょうと試みた。 カイコとハスモンヨトウに対する活性を PB併用下で測定 し，QSAR解析を行ったところ，それぞれ式 (14)，式（15） が得られた ${ }^{12)}$.

$$
\begin{aligned}
& \left.\mathrm{pLD}_{50} \text { (PB: B. mori }\right) \\
& =-1.25( \pm 0.59) \sigma+0.76( \pm 0.41) \pi-0.14( \pm 0.14) \pi^{2} \\
& -0.14( \pm 0.19) \Delta \mathrm{B} 5+6.12( \pm 0.33) \\
& n=20, \quad s=0.294, \quad r=0.834 \\
& \left.\mathrm{pLD}_{50} \text { (PB: S. litura }\right)= \\
& \begin{aligned}
& 2.51( \pm 0.62) \pi-0.44( \pm 0.16) \pi^{2} \\
&-0.53( \pm 0.18) \Delta \mathrm{B}_{5}+5.12( \pm 0.37) \\
& n=18, \quad s=0.308, \quad r=0.923
\end{aligned}
\end{aligned}
$$

式（14）（15）からわかるように，カイコでは電子的パラ メーターは通常の Hammett- $\sigma$ で表され， $\sigma$ 項の係数がマイナ スとなり, 八スモンヨトウでは電子効果は有意とならなかっ た．カイコに対しては，共力剂を用いない条件で求められた 活性 $\mathrm{pLD}_{50}$ (none) の結果は式（14）の結果とはほとんど変 わらなかった。この理由として，カイコは永年にわたって， 人工飼育されてきたことによって，異物代謝機能が大きく低 下していて, 本来の電子供与性基が望ましいとする置換基効 果が現れていると推察される。一方，八スモンヨトウでは, ニカメイチュウほどには酸化代謝能は高くないため, 本来の 活性におよぼす電子供与性効果と酸化代謝分解を受けにくく する電子求引性効果が度相殺されて, 電子的効果が有意に ならなかったと結論された。

フェニル側置換基効果で, 共力剤 PBを用いると, 活性に 対する電子求引性効果が低下すること, 昆虫種間で, 電子 的効果が様々であることから, 酸化代謝と置換基の電子効 果の関係に関する貴重な情報が得られることを期待して，in vitroで活性を評価した。通常は, 組織や細胞で活性評価を 行うと，代謝による解毒を考える必要はないと考えられる. そこで，二カメイチュウの培養表皮系を用いて，キチン合成 阻害活性を定量的に測定する検定系を構築した. 脱皮ホルモ ンで表皮に脱皮を誘導した後，キチンの前駆体である $N$-ア セチルグルコサミンの ${ }^{14} \mathrm{C}$ 標識体を含む培地でさらに 3 日間 培養して表皮に取り込まれる放射能を測定するという方法で ある. 先に述べたように, 最初は, 代謝分解による要因を考 える必要はないと考えたが, 培養表皮には脂肪体（昆虫で は, 酸化代謝にかかわっている) が付着していること, 活性 測定值が得られるまでに 3 日間の培養が必要であるので, 代 謝分解の可能性を考慮することを必要と考えた。実際, PB 
を共力剤として用いるといくつかの化合物で活性が顕著に増 大することがわかった．置換誘導体に対してin vitroの活性 を，共力剤を用いない条件と PB併用下で評価した（表9）. 共力剤を含まない培地で評価した活性 $\mathrm{pIC}_{50}$ (None) と $\mathrm{PB}$ を 培地に添加して求めた活性 $\mathrm{pIC}_{50}(\mathrm{~PB})$ をそれぞれ解析する と, 式（16），(17）が得られた ${ }^{14)}$.

$$
\begin{gathered}
\mathrm{pIC}_{50}(\text { None })=2.13( \pm 0.98) \sigma_{\mathrm{I}}+1.28( \pm 0.71) \pi \\
-0.28( \pm 0.40) \pi^{2}+5.69( \pm 0.43) \\
n=15, \quad s=0.375, \quad r=0.916 \\
\mathrm{pIC}_{50}(\mathrm{~PB})=-0.59( \pm 0.50) \sigma+1.49( \pm 0.50) \pi \\
-0.57( \pm 0.27) \pi^{2}+7.19( \pm 0.22) \\
n=15, \quad s=0.267, \quad r=0.916
\end{gathered}
$$

$\mathrm{pIC}_{50}$ (None) の QSAR解析においては， $\sigma_{\mathrm{I}}$ が電子効果とし て有意となり, $\mathrm{pIC}_{50}(\mathrm{~PB})$ のQSARでは $\sigma$ が有意となって, 係数は負となった。この結果は各種昆虫に対する殺虫活性に おけるQSARの結果［式（14），(15)］と矛盾しない。すな わち, 二カメイチュウのような害虫では酸化代謝能が高く, PB併用下でも酸化代謝を完全に抑えることができず，代謝 抑制に対する電子求引効果が正に働く [式 (2), (4)-(10)],
逆に，代謝能が低下していると考えられるカイコでは，本 質的な活性におよぼす電子効果が現れたと考えられた［式 (17)].

以上，BPU類のQSARについては，詳細に検討を行っ たが，最後に残った課題がある。それは，酸化代謝阻害剂 PBを併用しない条件でニカメイチュウに対して求めた活性

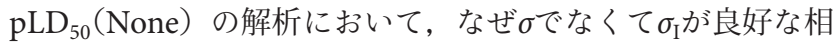
関関係を与えるかということである.酸化反応は一個の電 子を失うラジカル生成反応であるので, ラジカル反応にお ける電子効果との関係を調べてみた。すなわち, ラジカル 反応に打ける $\sigma$ 定数 $\left(\sigma^{*}\right)$ の值が求められている 12 の置換 基 $\left(\mathrm{H}, \mathrm{CH}_{3}, \mathrm{~F}, \mathrm{Cl}, \mathrm{Br}, \mathrm{I}, \mathrm{NO}_{2}, \mathrm{CN}, \mathrm{OCH}_{3}, \mathrm{~N}=\mathrm{NPh}\right.$, $\left.\mathrm{COCH}_{3}, \mathrm{Ph}\right)$ について $\sigma_{\mathrm{I}}$ と $\sigma^{*}$ との関係について解析したと ころ相関関係は必ずしも良好とは言えないが， $\sigma_{I}$ は $\sigma と \sigma \cdot に$ よって式（18）のように有意に関係づけられた。

\begin{tabular}{|c|c|c|c|c|c|c|c|c|c|c|c|}
\hline \multirow{3}{*}{ No. } & \multirow{3}{*}{ 置換基 } & \multicolumn{5}{|c|}{$\mathrm{pIC}_{50}{ }^{a)}$} & & \multirow{2}{*}{\multicolumn{4}{|c|}{ 置換基パラメーター }} \\
\hline & & \multicolumn{2}{|c|}{ None } & \multicolumn{3}{|c|}{$\mathrm{PB}$} & & & & & \\
\hline & & 実測值 & $\begin{array}{l}\text { 計算值 } \\
\text { 式 }(16)\end{array}$ & 差 ${ }^{b)}$ & 実測值 & $\begin{array}{l}\text { 計算值 } \\
\text { 式 }(17)\end{array}$ & 差 ${ }^{c)}$ & $\pi$ & $\sigma$ & $\sigma_{\mathrm{I}}$ & $\sigma^{\cdot d)}$ \\
\hline 1 & $\mathrm{H}$ & 5.19 & 5.69 & -0.50 & 6.79 & 7.19 & -0.40 & 0.00 & 0.00 & 0.00 & 0.00 \\
\hline 2 & $\mathrm{~F}$ & 7.51 & 7.21 & 0.30 & 7.80 & 7.56 & 0.24 & 0.31 & 0.06 & 0.54 & -0.25 \\
\hline 3 & $\mathrm{Cl}$ & 7.69 & 7.66 & 0.03 & 7.72 & 7.96 & -0.24 & 0.96 & 0.23 & 0.47 & 0.08 \\
\hline 4 & $\mathrm{Br}$ & 8.14 & 7.78 & 0.36 & 8.28 & 8.01 & 0.27 & 1.13 & 0.23 & 0.47 & 0.17 \\
\hline 5 & I & 7.88 & 7.73 & 0.15 & 8.20 & 8.06 & 0.14 & 1.30 & 0.18 & 0.40 & 0.16 \\
\hline 6 & $\mathrm{CH}_{3}$ & 6.48 & 6.27 & 0.21 & 7.86 & 7.93 & -0.07 & 0.54 & -0.17 & -0.01 & -0.02 \\
\hline 7 & Et & 6.54 & 6.69 & -0.15 & 8.12 & 8.21 & -0.09 & 1.04 & -0.15 & -0.01 & \\
\hline 8 & $n-\operatorname{Pr}$ & 7.15 & 6.91 & 0.24 & 8.45 & 8.24 & 0.21 & 1.40 & -0.13 & -0.01 & \\
\hline 10 & $n-\mathrm{Bu}$ & 7.34 & 7.13 & 0.22 & 7.96 & 7.88 & 0.08 & 2.14 & -0.16 & -0.01 & \\
\hline 15 & $\mathrm{OCH}_{3}$ & 6.04 & 6.15 & -0.11 & 7.28 & 7.15 & 0.13 & -0.13 & -0.27 & 0.30 & -0.12 \\
\hline 16 & $\mathrm{OC}_{2} \mathrm{H}_{5}$ & 6.53 & 6.66 & -0.13 & 7.62 & 7.75 & -0.13 & 0.32 & -0.24 & 0.28 & \\
\hline 19 & $\mathrm{NO}_{2}$ & 7.06 & 7.68 & -0.62 & 7.07 & 7.33 & -0.26 & 0.50 & 0.78 & 0.67 & 0.27 \\
\hline 20 & $\mathrm{CN}$ & 7.28 & 6.94 & 0.34 & 7.27 & 6.85 & 0.43 & 0.03 & 0.66 & 0.57 & 0.34 \\
\hline 14 & $\mathrm{~N}=\mathrm{NPh}$ & 7.16 & 7.71 & -0.55 & 7.48 & 7.74 & -0.26 & 1.91 & 0.39 & 0.28 & 0.33 \\
\hline 151 & $\mathrm{CH}_{2} \mathrm{CN}$ & 5.66 & 5.45 & 0.21 & 6.32 & 6.36 & -0.04 & -0.47 & 0.01 & 0.20 & \\
\hline 40 & $\mathrm{Ph}$ & & & & & & & 1.96 & 0.01 & 0.12 & 0.12 \\
\hline 152 & $\mathrm{COCH}_{3}$ & & & & & & & -0.06 & 0.50 & 0.30 & 0.53 \\
\hline
\end{tabular}

$$
\begin{gathered}
\sigma_{\mathrm{I}}=0.87( \pm 0.45) \sigma-0.80( \pm 0.67) \sigma+0.263( \pm 0.11) \\
n=12, \quad s=0.136, \quad r=0.829
\end{gathered}
$$

式（18）の結果から以下のように推論される. 酸化的代謝 が完全に抑制されていない場合，B環置換基の電子効果とし

表9. 培養表皮系におけるBPU類のキチン合成阻害活性と置換基定数

a) 空欄：測定值なし. ${ }^{b)}$ 実測值 $\left[\mathrm{pIC}_{50}(\mathrm{None})\right]$ から式（16）による計算值を差し引いた值. ${ }^{c)}$ 実測值 $\left[\mathrm{pIC}\right.$ ( $\left.{ }_{50}(\mathrm{~PB})\right]$ から式（17）によ る計算值を差し引いた值. ${ }^{d)}$ 空欄：文献値なし. 
て正の $\sigma_{\mathrm{I}}$ 項は, ラジカル反応的電子求引性 $\sigma^{\circ}$ の值が負の方 向に大きいほど, また, 通常の電子誘起効果が大きいほど, 大きくなる．すなわち，もともと活性は置換基の電子求引性 （ $\sigma$ で表される）の大きいほど高いが，ラジカル生成，すなわ ち酸化代謝されやすいほど $\sigma^{*}$ パラメーターの変化に応じて 低下することがわかる。 したがって, 酸化代謝による解毒能 が高い条件下で求められたニカメイチュウでは電子効果とし て通常の $\sigma て ゙ な く \sigma_{I}$ が有意になったと考えられる.

BPU類のin vivoから in vitroの活性に対する QSARの展開 の中で得られた情報は, BPU類の標的タンパク質が明らか にされた際には, 輸送過程, 分子レベルにおける相互作用解 明において重要な知見となるであろう.

\section{おわりに}

ベンゾイルフェニルウレア類のQSARは, 筆者が大学院 生であった当時から約 10 年間に亘って積み上げてきた体験 にもとづくものである. QSARの実際は活性指標やパラメー ターを単に数值として取り扱うのではなく，その背景として 作用の発現に関する有機物理化学機構を明らかにしようとす る意義があることを理解いただければ幸甚である．最後にな りましたが，本稿を執筆する機会を与えていただいた安藤哲 編集委員長に感謝するとともに，本稿執筆にあたり，ご助言 を頂戴した藤田稔夫先生にはこころから御礼申し上げます。

\section{引 用 文 献}

1) C. Hansch and T. Fujita: JACS 86, 1616-1626 (1964).

2) J. J. van Daalen, J. Meltzer, R. Mulder and K. Wellinga: Naturwissenschaften 59, 312-313 (1972).

3) 中川好秋：農薬誌 21, 460-467 (1996).

4) 中川好秋: 脱皮と変態の生物学, 園部治之, 長澤寛道編, 東海大 学出版会, pp.147-166, 2011.

5) K. Wellinga, R. Mulder and J. J. van Daalen: J. Agric. Food Chem.
21, 993-998 (1973).

6) 芳賀隆弘, 土岐忠昭, 辻井康弘, 西山隆三: 農薬誌 17, S103S113 (1992).

7）芳賀隆弘：脱皮と変態の生物学, 園部治之, 長澤寛道編, 東海大 学出版会, pp. 211-228, 2011.

8）池田健一, 安井通宏, 菅野英夫, 前川定文: 農薬誌 11, 287-295 (1986).

9）鈴木純二, 石田達也, 渋谷一郎, 戸田和哉：農薬誌 $25,215-223$ (2001).

10) Y. Nakagawa, K. Kitahara, T. Nishioka, H. Iwamura and T. Fujita: Pestic. Biochem. Physiol. 21, 309-325 (1984).

11) Y. Nakagawa, T. Sotomatsu, K. Irie, K. Kitahara, H. Iwamura and T. Fujita: Pestic. Biochem. Physiol. 27, 143-155 (1987).

12) Y. Nakagawa, T. Akagi, H. Iwamura and T. Fujita: Pestic. Biochem. Physiol. 33, 144-157 (1989).

13) Y. Nakagawa, M. Matsutani, N. Kurihara, K. Nishimura and T. Fujita: Pestic. Biochem. Physiol. 42, 242-247 (1992).

14) Y. Nakagawa, M. Matsutani, N. Kurihara, K. Nishimura and T. Fujita: Pestic. Biochem. Physiol. 43, 141-151 (1992).

15) Y. Nakagawa, H. Iwamura and T. Fujita: Pestic. Biochem. Physiol. 23, 7-12 (1985).

16) Y. Nakagawa, K. Izumi, N. Oikawa, T. Sotomatsu, M. Shigemura and T. Fujita: Environ. Toxicol. Chem. 11, 901-916 (1992).

17) 中川好秋：農薬誌 21, 363-377 (1996).

18）藤田稔夫：農薬誌 38, 2-19 (2013)

19）赤松美紀：農薬誌 38, 195-203 (2013).

20) Y. Nakagawa, T. Akagi, H. Iwamura and T. Fujita: Pestic. Biochem. Physiol. 30, 67-78 (1988).

21) Y. Nakagawa, K. Izumi, N. Oikawa, A. Kurozumi, H. Iwamura and T. Fujita: Pestic. Biochem. Physiol. 40, 12-26 (1991).

22) C. Hansch, C. Grieco, C. Silipo and A. Vittoria: J. Med. Chem. 20, 1420-1435 (1977).

23) T. Sotomatsu and T. Fujita: J. Org. Chem. 54, 4443-4448 (1989).

24) T. Sotomatsu, M. Shigemura, Y. Murata and T. Fujita: J. Pharm. Sci. 82, 776-781 (1993).

25) T. Sotomatsu, Y. Nakagawa and T. Fujita: Pestic. Biochem. Physiol. 27, 156-164 (1987). 